\title{
26. ORGANIC GEOCHEMISTRY OF GASES, FLUIDS, AND HYDRATES AT THE CASCADIA ACCRETIONARY MARGIN ${ }^{1}$
}

\author{
Michael J. Whiticar, ${ }^{2}$ Martin Hovland, ${ }^{3}$ Miriam Kastner, ${ }^{4}$ and James C. Sample ${ }^{5}$
}

\begin{abstract}
The drilling during Ocean Drilling Program Leg 146 at the accretionary margin complexes off Vancouver Island, Canada (VIM), and Oregon, U.S.A (COM), addressed specific geochemical relationships and phenomena associated with fluid, gas, and heat fluxes generated by the compressive forces. Of particular importance were the occurrence of hydrates and formation of thermogenic hydrocarbons. In most cases, the geochemistry of the hemipelagic sediments is dominated by steady-and nonsteady-state diagenetic reactions, including sulfate reduction (Sites 888 and 891), and methanogenesis and methanotrophy (Sites $888-892)$. However, these shallow ( $<600 \mathrm{mbsf}$ ) sediments are also clearly and extensively influenced by pervasive and active fracture COM migration of deeper seated thermogenic hydrocarbons at the VIM and COM, respectively. The origin of bacterial and thermogenic gases is confirmed by their molecular and stable carbon isotope signatures. In many cases, the occurrence of $\mathrm{C}_{2}+$ hydrocarbons delineates the fault zones.

Only disseminated macrocrystalline hydrate, not massive hydrate, was encountered during Leg 146. Based on the carbon isotope signature, the hydrate is of bacterial origin and identical to that of the surrounding sediment free gas. Thermogenic gas hydrates were not encountered. The discrepancy between the location of the bottom-simulating reflector (BSR) and the base of hydrate stability may be caused by the presence of other gases or fluid constituents in the hydrate lattice. The amount of free gas inferred by the vertical seismic profiler (VSP) below the BSR may be due to the incomplete upward cryo-distillation of gases. This vertical shift could be created by (1) the change in bottom-water temperatures between glacial and interglacial, and (2) a pressure drop caused by sea-level change and accretionary uplift. The presence of hydrogen sulfide in the methane hydrates at Site 892 was unexpected and results from the rapid incorporation of $\mathrm{H}_{2} \mathrm{~S}$ into hydrates, protecting them from reaction, (e.g., formation of iron monosulfides.)
\end{abstract}

\section{INTRODUCTION}

The drilling on the convergent accretionary margins off Oregon and Vancouver Island during the Ocean Drilling Program (ODP) Leg 146 represented an opportunity to establish relationships between diagenesis, catagenesis, fluid flow, and hydrate occurrence in oceanic accretionary wedges at tectonically active regions. Compressive forces at the accretionary margin complexes off Vancouver Island, Canada, and Oregon, U.S.A., are expressed by several geochemical features. Surficial manifestations include pockmarks, carbonate pavements, and local oases of life, all resulting from the expulsion of pore fluids. In the subsurface, hydrates and thermogenic gases are clear indicators of the gas and, possibly, fluid migration.

Five sites were occupied at two distinct study areas along the Cascadia Margin: (1) Vancouver Island Margin (VIM), Sites 888, 889, and 890; and (2) Central Oregon Margin (COM), Sites 891 and 892 (Fig. 1). Westbrook, Carson, Musgrave, et al. (1994) have described in detail the basic geologic, geophysical and geochemical settings of these locations.

The proximity of both the VIM and COM study regions to the Juan de Fuca Ridge spreading center means that the subducting oceanic crust is relatively young ( $\sim \mathrm{Ma}$ and $8 \mathrm{Ma}$, respectively) and that the regions have higher heat fluxes than those underlying older crust (e.g., Site $889 \approx 140 \mathrm{~mW} \mathrm{~m}^{-2}$, Site $892 \approx 53 \mathrm{~mW} \mathrm{~m}^{-2}$; Davis et al.,

Carson, B., Westbrook, G.K., Musgrave, R.J., and Suess, E. (Eds.), 1995. Proc ODP, Sci. Results, 146 (Pt. 1): College Station, TX (Ocean Drilling Program).

${ }^{2}$ School of Earth and Ocean Sciences, University of Victoria, Victoria, British Columbia V8W 2Y2, Canada.

${ }^{3}$ Statoil, P.O. Box 300, N-4001 Stavanger, Norway.

${ }^{4}$ Scripps Institute of Oceanography, University of California, San Diego, La Jolla, CA 92093, U.S.A.

'Department of Geological Sciences, California State University, Long Beach, CA 90840-3902, U.S.A.
1990; Westbrook, Carson, Musgrave, et al., 1994). Seismic reflection studies at both regions have revealed bottom-simulating reflectors (BSRs) that are attributable to the presence of gas hydrates, that is, clathrated hydrocarbon and non-hydrocarbon gases.

Despite VIM and COM both being part of the Cascadia Margin accretionary complex, the two areas display significantly different geologic settings, (discussed in detail by Yorath, 1987; Hyndman et al., 1990; Westbrook, Carson, Musgrave, et al., 1994).

At VIM, post-Eocene, oceanic sediments are being scraped off the subducting Juan de Fuca Plate and being accreted onto the North American Plate. Most of these sediments are turbidites and hemipelagites, with a major terrigenous component. Multichannel seismic data have been used by Davis and Hyndman (1989) and Hyndman and Davis (1992) to model porosity and heat flow at VIM. Based on these results, the fluid flow at VIM can be characterized as laterally homogeneous, unfocused or diffuse pore fluid expulsion.

In contrast to VIM, the COM exhibits extensive thrusting at the deformation front of the accretionary wedge (Snavely, 1987; Moore et al., 1990; MacKay et al., 1992). A result of this is a focused pore fluid expulsion along fracture zones at the COM. This fluid flow has been recognized in the region as sediment surface manifestations of pore waters and methane gas, venting called "cold seeps" (e.g., Kulm et al., 1986; Ritger et al., 1987; Suess and Whiticar, 1989).

This synthesis paper discusses some of the organic geochemical expressions and consequences of these two fluid expulsion types. In particular, to be discussed for VIM and COM are:

1. variations in diagenesis and catagenesis;

2. the occurrence and molecular/stable carbon isotope characterization of bacterial and thermogenic gas;

3. occurrence of gas hydrates and relationship to gas distributions;

4. possibility of free gas beneath the hydrate zone; and

5 . influence of accretionary tectonics, heat, and fluid flow on organic geochemistry. 


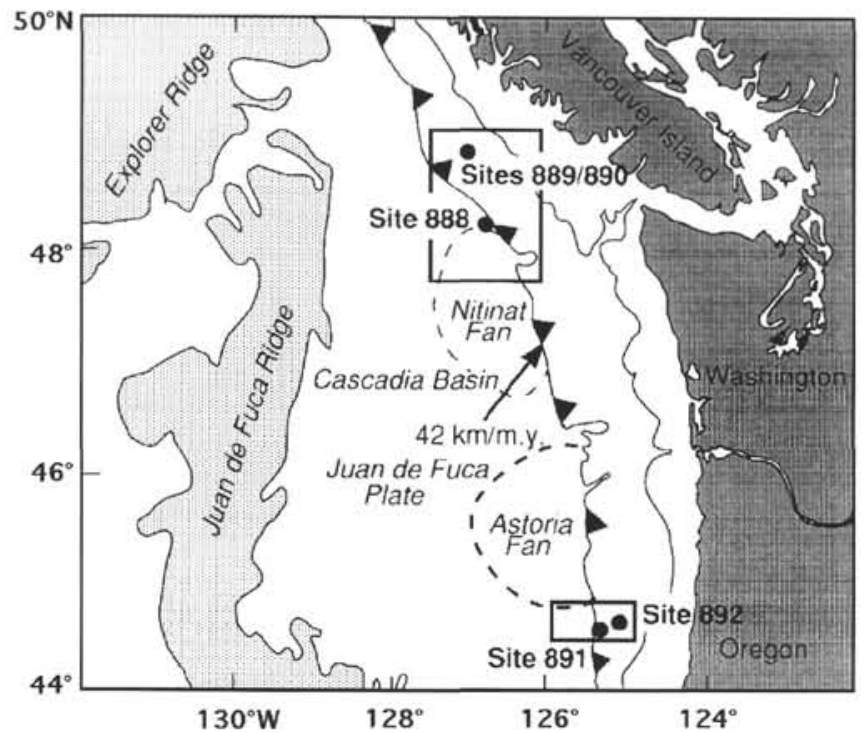

Figure 1. Location map of ODP Leg 146. Sites 888,889 , and 890 are located along the VIM; Sites 891 and 892 are on the COM.

\section{METHODS}

The sampling and analytical methods employed and the data generated have been described and reported in detail by the Explanatory Notes and respective Site Summaries of Whiticar et al., 1994; Whiticar, in press; Whiticar and Cederberg, in press; M.J. Whiticar and M. Hovland in Shipboard Scientific Party, 1994; M. Kastner and J. Sample in Shipboard Scientific Party, 1994; Hovland and Whiticar, this volume; Kastner et al., this volume, and the references contained therein. Interested readers are referred to these sources for the original descriptions and data reporting (tables and figures).

\section{Terminology and Concentration Notation}

Headspace gases are obtained by placing a $\sim 5 \mathrm{~mL}$ plug of the cored sediment into sealed glass vials $(10 \mathrm{~mL}$ Wheaton bottle). After heating the headspace gas in the vial is measured. Vacutainer or evacuated void gases (EVG) are taken directly after the cores are delivered to the catwalk immediately following their recovery on the drill floor. By seal-puncturing the core liners at locations of visible partings and voids in the sediment, gas samples are drawn into and stored until measurement in pre-evacuated Vacutainer vessels. Total gases were extracted from $\sim 3 \mathrm{~g}$ of frozen sediment sample in a technique developed by Whiticar (in press) for determining the sorbed and free gases (for details, see Whiticar and Hovland, this volume).

Gas concentrations were measured by gas chromatography (GC; M.J. Whiticar and M. Hovland in Shipboard Scientific Party, 1994). The concentration of methane in the sorbed gases is reported on a wet sediment weight basis, (i.e., $\mu \mathrm{g} \mathrm{CH}_{4} / \mathrm{kg}$ wet sediment). The gases measured by the headspace and Vacutainer/EVG methods are reported on a gas volumetric basis, parts per million by volume (ppmv), (e.g., $\mu \mathrm{l} \mathrm{CH} / \mathrm{L}$ sample). In the case of the Vacutainer/EVG, the partial pressures of the gases measured are similar to those in the gas pocket of the sediment core liner. Inherent in the sampling for the headspace measurement is considerable contamination of air in the vial prior to sealing. Hence, the abundances are only relative.

Interstitial fluids in the cored sediments were expressed immediately after sampling from cleaned sediment core or "biscuits" using the shipboard hydraulic presses. These pore fluids were then analyzed by conventional chemical techniques reported by Kastner and Sample, 1984, (i.e., sulfate by DIONEX ion chromatography and al- kalinity by automatic titration). The pore fluid constituents are reported in standard molar units.

\section{Stable Isotope Determinations and Notation}

The ${ }^{13} \mathrm{C} /{ }^{12} \mathrm{C}$ isotope ratios of methane were determined by a specially modified, on-line coupled Gas Chromatograph-CombustionIsotope Ratio Mass Spectrometer (GC/C/IRMS; Whiticar and Cederberg, in press). This technique permits routine and rapid determination of $\mathrm{C}$-isotope ratios on sub-nanomolar quantities of hydrocarbons.

For analytical reasons, such as source pressure, ionization efficiency and ion beam stability, stable isotope data are determined as a ratio (for example, ${ }^{13} \mathrm{C} /{ }^{12} \mathrm{C}$ ), rather than as absolute atomic or molecular abundances. These ratios are reported as the magnitude of excursion in per mil (\%) of the sample isotope ratio relative to a known standard isotope ratio. The usual $\delta$-notation generally used in earth sciences is:

$$
\left.\delta^{13} \mathrm{C}(\%)=\frac{{ }^{13} \mathrm{C} /{ }^{12} \mathrm{C} \text { sample }}{{ }^{13} \mathrm{C} /{ }^{12} \mathrm{C} \text { standard }}-1\right) \times 10^{3}
$$

where the isotope ratio ${ }^{13} \mathrm{C} /{ }^{12} \mathrm{C}$ is referenced relative to the PDB standard.

\section{DIAGENESIS AT THE CASCADIA MARGIN}

Two diagenetic regimes dominate at both the VIM and COM locations. At all sites, the sediments encountered are strictly anoxic, with perhaps the exception of the uppermost meter section of Site 888 (Fig. 2). Bacterial sulfate reduction and methanogenesis are operating at all sites and together their occurrences and distributions are perhaps the parameters that most clearly distinguish the two diagenetic types. However, sediment accumulation rate, organic matter quality, and the influence of fluid flow are additional determining factors for the respective type 1 and type 2 diagenetic systems defined in Table 1.

The exceptional near-surface samples at Site 888 have dissolved sulfate concentrations more similar to that of the overlying water column. The presence of bottom-water sulfate levels in the surface sediments of Site 888 suggests that sulfate reduction is not occurring and that these uppermost sediments may be aerobic. Geochemical analyses of shallow 5-10 m of sediment cored previously in sediments adjacent to the Site 888 (Davis et al., 1992) showed similar sulfate distributions. There, the uppermost meter of sediment is aerobic, followed by anaerobic sediments at greater depth with sulfate reduction and methanogenesis (also see Cragg et al., this volume).

\section{Sediment Accumulation Rates and Organic Carbon Contents}

Sites 888 and 891 can be characterized as having higher sediment accumulation rates, and Sites $889 / 890$ and 892 have lower rates. The average rate of sediment accumulation is estimated to be 900 and $>590 \mathrm{~m} / \mathrm{m}$.y. for Sites 888 and 891 , respectively (Table 1). For comparison, this sediment accumulation rate is up to nine times more rapid than at Site $889(110 \mathrm{~m} / \mathrm{m} . \mathrm{y}$.$) or four times faster than that of Site$ $892(220 \mathrm{~m} / \mathrm{m} . \mathrm{y}$.).

At Site 888 , organic carbon contents $\left(\mathrm{C}_{\text {org }}\right)$ fluctuate about 0.4 wt $\%$ with a range from 0.2 to $0.6 \mathrm{wt} \%$ (Table 2). At Site $891, \mathrm{C}_{\mathrm{org}}$ is typically around $0.2 \mathrm{wt} \%$ with narrow excursions up to $0.8 \mathrm{wt} \%$. These are significantly lower $\mathrm{C}_{\text {org }}$ values than at Sites 889 and 892 ( 1.0 and $1.5 \mathrm{wt} \%$; Table 2), where the accumulation rate is much lower. This apparently contradicts the conventional understanding of higher $\mathrm{C}_{\mathrm{org}}$ values at greater accumulation rates, and of higher deposition in nearer shore environments (Müller and Suess, 1979). This 


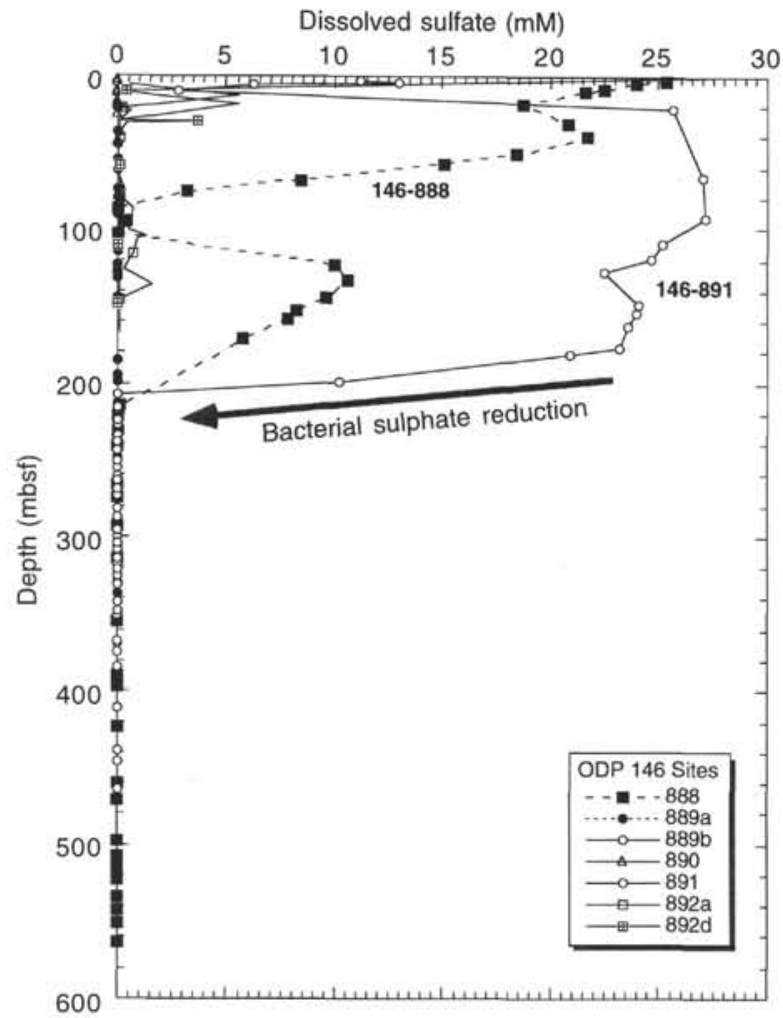

Figure 2. Depth distributions of dissolved sulfate concentrations in the interstitial fluids of Leg 146. With the exception of Sites 888 and 891, sulfate was exhausted in the uppermost 20 mbsf. Both Sites 888 and 891 exhibit nonsteady state $\mathrm{SO}_{4}{ }^{2-}$ profiles.

Table 1. Estimated rates of sediment accumulation.

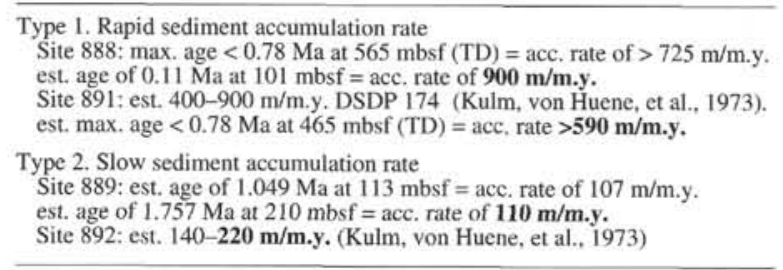

departure from passive margin depositional regimes illustrates the atypical sedimentological nature of these accretionary settings. The organic matter type and quantity do not appear to exert obvious diagenetic control. With the exception of Site 889 , where the sedimentary organic matter is dominantly of marine origin as indicated by the $\mathrm{C} / \mathrm{N}$ ratio of $7: 1$ (Table 2), the $\mathrm{C}: \mathrm{N}$ at Sites 888,891 , and 892 was around 10:1, indicative of a mixed marine/terrestrial source. This is expected for the North East Pacific environment with its typically high terrestrial clastic/humic contribution from the adjacent continent. It should be noted that at these lower $\mathrm{C}_{\text {org }}$ levels the $\mathrm{C} / \mathrm{N}$ ratios also may be influenced by inorganic nitrogen contributions, which could affect the reliability of the organic $\mathrm{C} / \mathrm{N}$ ratios.

\section{Sulfate Distribution and Bacterial Sulfate Reduction}

Bacterial sulfate reduction is a feature common to the sediments at all the Leg 146 Sites. With one possible exception, the dissolved sulfate concentration in all the holes was significantly less than the 28 $\mathrm{mM} \mathrm{SO}{ }_{4}{ }^{2-}$ expected for the conservative burial of water from the overlying water column (Fig. 2). This indicates that the sediments are anaerobic and undergo bacterial sulfate reduction (see Cragg et al., this volume). The possible exception is the uppermost sample at Hole 892D (1X-1, 9-12 cm) at $0.09 \mathrm{mbsf}$, which has a dissolved sulfate concentration of $27.65 \mathrm{mM}$, close to the overlying water $\mathrm{SO}_{4}{ }^{2-}$ concentration. Alternatively, the higher sulfate concentration at this interval may be due to contamination of the sample by seawater. At Sites 888 and 891 , sulfate persists to the greatest sediment depth, of $\sim 200$ mbsf (Fig. 2). Both of these sites also displayed unusual $\mathrm{SO}_{4}{ }^{2-}$ concentration distributions, with non-steady state $\mathrm{SO}_{4}{ }^{2-}$ concentration minima within the sulfate reduction zone. In addition, Sites 888 and 891 have the highest sediment accumulation rates and lowest $\mathrm{C}_{\text {org }}$ contents (Tables 1,2). Sulfate at the other sites $(889,890$, and 892) decreases rapidly with depth and is generally exhausted (i.e., at concentrations below the detection limit $[<0.01 \mathrm{mM}]$ ) at depths below 30 mbsf.

Sulfate consumption in the surface zone, between 0 and $30 \mathrm{mbsf}$, is the most rapid at Site 891 , with an approximate rate of $0.1 \mathrm{mM}$ $\mathrm{SO}_{4}{ }^{2-} \mathrm{y}^{-1}$ (Fig. 3). This sulfate reduction rate is calculated directly from the gradient and is not corrected for diffusion, advection or sorption effects. Figure 3 uses the bulk sediment accumulation rates of Table 1 to calculate the approximate ages. The sulfate level drops to $2.8 \mathrm{mM}$ at $9.27 \mathrm{mbsf}$ at Site $891(3 \mathrm{H}-2,53-68 \mathrm{~cm})$, then returns to $25.6 \mathrm{mM}$ within the next $10-\mathrm{m}$ sediment depth (Fig. 2). The explanation for this feature is not clear, but the decrease in $\mathrm{SO}_{4}{ }^{2-}$ is associated with a commensurate rise in alkalinity, and there is no chloride anomaly. Sulfate at Site 891 decreases little in the interval between 30 and 180 mbsf. Below $180 \mathrm{mbsf}$, sulfate concentrations drop rapidly ( $0.04 \mathrm{mM} \mathrm{SO}_{4}{ }^{2-} \mathrm{y}^{-1}$, Fig. 3), analogous to the surface sediments higher in the hole. Sulfate is exhausted at $210 \mathrm{mbsf}$ (Fig. 2).

Bacterial sulfate reduction at Site 888 completely removes sulfate by $220 \mathrm{mbsf}$ (Fig. 2), although a very unusual diagenetic feature, discussed later, was observed around $80 \mathrm{mbsf}$. Extrapolation of the sulfate concentration linearly from the surface to $220 \mathrm{mbsf}$ yields a sulfate reduction rate of $\sim 5 \mathrm{mM} / 10^{3} \mathrm{y}$, although higher rates of 0.02 $\mathrm{mM} \mathrm{SO}_{4}{ }^{2-} \mathrm{y}^{-1}$ are observed for some intervals (e.g., 40-80 mbsf, Fig. 3).

Sulfate concentrations at Sites 889,890 , and 892 dropped quickly at the surface and then remained with further depth in the core close to, or below, detection limit (Fig. 2). Bacterial sulfate reduction was intense at these three sites, generally $>0.1 \mathrm{mM} \mathrm{SO}_{4}{ }^{2-} \mathrm{y}^{-1}$ (Fig. 3).

The rate of bacterial sulfate reduction is regulated by substrate availability in abundant sulfate environments. Subsequently, sulfate reduction is a first-order sulfate-controlled system in low sulfate conditions (e.g., Iversen and Jørgensen, 1985). Sediment accumulation and burial rates are largely responsible for the differences between the two environments, as is the downward diffusion of sulfate along the concentration gradient from the overlying water column (also see Cragg et al., this volume). It is also possible that the lower $\mathrm{C}_{\text {org }}$ contents, and perhaps more recalcitrant organic matter, at Sites 888 and 891 , contribute to the lower sulfate reduction rates.

Even though some of the reduced sulfur can be bound up in organic matter, the majority of the sulfides react to form iron monosulfides, which ultimately leads to pyrite formation. Typically, sulfide does not persist very long in iron-rich sediments $\left(\sim 10^{2}-10^{3} \mathrm{yr}\right)$ and the $\mathrm{H}_{2} \mathrm{~S}$ malodor observed in the most recent sediments, including Leg 146 sites, disappears rapidly with depth in the hole as hydrogen sulfide is complexed and removed.

At Site 892, we unexpectedly encountered extremely high and dangerous levels of hydrogen sulfide. In Hole $892 \mathrm{~A}, \mathrm{EVG}$ samples had over $10,700 \mathrm{ppmv}_{2} \mathrm{~S}$ in the second section of the first core (1.78 mbsf; Fig. 4) and persisted to 15 mbsf, below which $\mathrm{H}_{2} \mathrm{~S}$ decreased rapidly to undetectable level by $81 \mathrm{mbsf}$. Similarly, at Hole 892D, levels of $\mathrm{H}_{2} \mathrm{~S}$ up to 19,500 ppmv were present in the uppermost 22 mbsf. It is not thought that the interstitial fluids contained these extraordinarily high $\mathrm{H}_{2} \mathrm{~S}$ concentrations or were iron-poor; rather, as is 
Table 2. Organic carbon contents and $\mathrm{C} / \mathrm{N}$ ratios.

\begin{tabular}{ccccccc}
\hline Site & $\begin{array}{c}\text { Avg. } \\
(\mathrm{wt} \%) \mathrm{C}_{\text {org }}\end{array}$ & Range & $\begin{array}{c}\text { Ref. } \\
\text { figure }\end{array}$ & C:N & $\begin{array}{c}\text { Source } \\
\text { (s) }\end{array}$ & $\begin{array}{c}\text { Ref. } \\
\text { figure }\end{array}$ \\
\hline 888 & 0.4 & $0.2-0.6$ & $888-32$ & $10: 1$ & Mixed marine/terrestrial & $888-33$ \\
889 & 1.0 & $0.4 \rightarrow 1.4$ & $889-55$ & $7: 1$ & Primarily marine & $889-56$ \\
891 & 0.2 & $0.2-0.8$ & $891-29$ & $10: 1$ & Mixed marine/terrestrial & $891-31$ \\
892 & 1.5 & $1.0->1.9$ & $892-36$ & $10: 1$ & Mixed marine/terrestrial & $892-37$ \\
\hline
\end{tabular}

Note: Figures cited in "Ref." are from Westbrook, Carson, Musgrave, et al., 1994

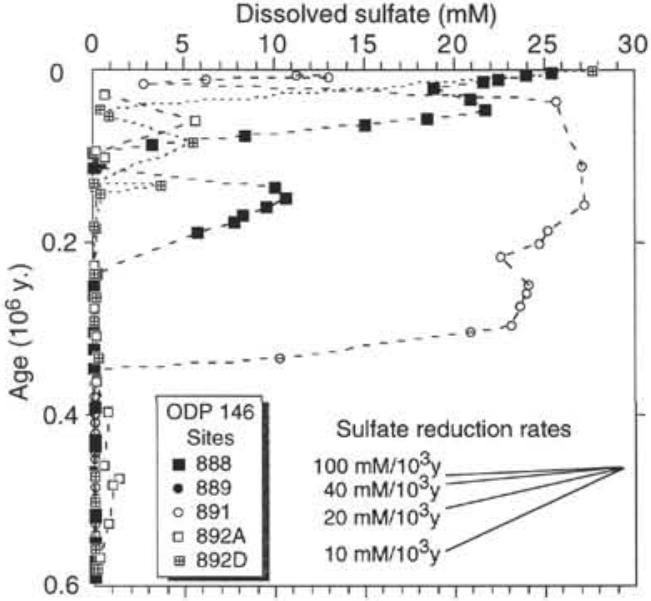

Figure 3. Sulfate reduction rates based simply on $\mathrm{SO}_{4}{ }^{2-}$ gradients and estimated accumulation rates (Table I).

discussed later, these high $\mathrm{H}_{2} \mathrm{~S}$ contents are caused by the dissociation of sulfide-rich gas hydrates in the surface sediments. The sequestering of the sulfide into the clathrate structure essentially removes it from further reaction with ferrous iron complexation. The rapid decomposition of the sulfide-hydrate due to pressure drop and warming upon core recovery spontaneously releases large amounts of $\mathrm{H}_{2} \mathrm{~S}$ into the headspace and interstitial fluids.

\section{Alkalinity and Remineralized Nitrogen and Phosphorus}

The extensive removal of sulfate by the sulfate-reducing bacteria (SRBs) during the remineralization of organic matter should result in the stoichiometric release of dissolved nutrients into the interstitial fluids according to Redfield's ratios. An increase in alkalinity should be inversely proportional to the sulfate consumed. At the sites with the most rapid removal of sulfate (i.e., Sites 889,890 , and 892 ), there is a commensurate rise in alkalinity from the seawater values of 2.3 $\mathrm{meq} / \mathrm{L}$ to $>40 \mathrm{meq} / \mathrm{L}$ at Site $889,>30 \mathrm{meq} / \mathrm{L}$ at 890 , and $>10 \mathrm{meq} / \mathrm{L}$ at Site 892 (Fig. 5). At Sites 888 and 891 , the alkalinity also rises, albeit first at greater sediment depth, to $>30 \mathrm{meq} / \mathrm{L}$ and $>28.9 \mathrm{meq} / \mathrm{L}$, respectively. The alkalinity regeneration appears at first glance to track the uptake of sulfate, but these stoichiometries are not consistent. Carbonate $\left(\mathrm{CaCO}_{3}\right)$ precipitation and methanogenesis, discussed next, are among the processes that are responsible for the discrepancy,

However, at the depth where sulfate is exhausted and methane starts to accumulate, the alkalinity clearly, and in all cases, decreases with increasing depth. This drop in alkalinity is associated with the fermentative utilization of bicarbonate by the methanogens (Claypool and Kaplan, 1974). This causes a preferential loss of alkalinity and is confirmed by comparing it to dissolved ammonia in the interstitial fluids. Ammonia generally increased to a depth of $100 \mathrm{mbsf}$ to $350 \mathrm{mbsf}$, then either decreased with further depth (Sites 888, 889, 891 ) or remained constant (Site 892; see Westbrook, Carson, Mus-

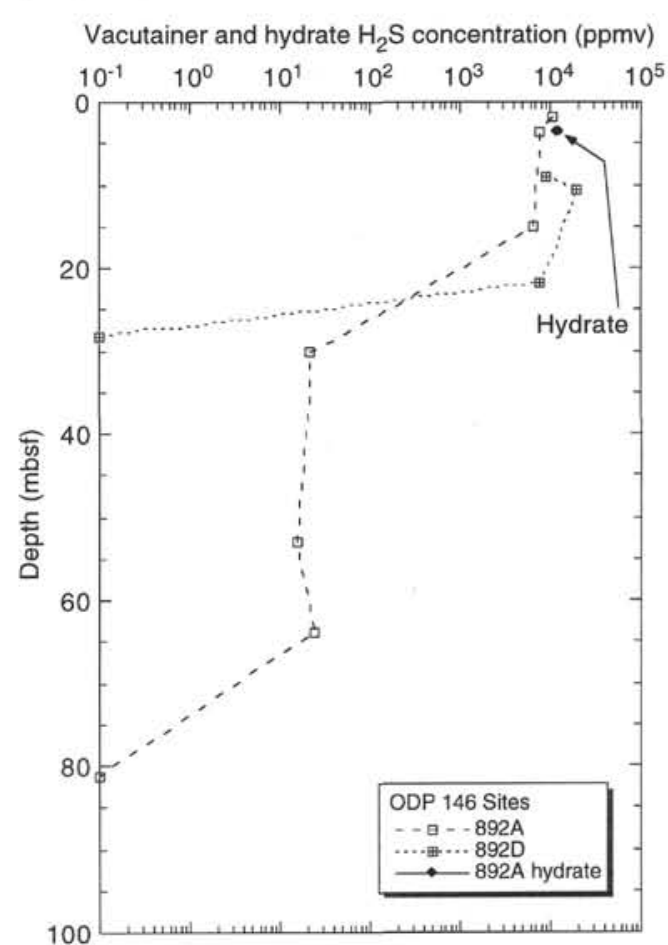

Figure 4. Depth distributions of dissolved $\mathrm{H}_{2} \mathrm{~S}$ in the interstitial fluids of Leg 146. The concentration of $\mathrm{H}_{2} \mathrm{~S}$ in the hydrate is also shown.

grave, et al., 1994; i.e., "Site 888 " chapter, fig. 41 ; "Site 889 " chapter, fig. 64; "Site 891" chapter, fig. 38; "Site 892" chapter, fig. 45).

The strong distinction observed between Sites $888 / 891$ and Sites $889 / 890 / 892$ is also reflected in the carbon isotope ratio of dissolved inorganic carbon ( $\delta^{13} \mathrm{C}$-DIC; Fig. 6). Figure 6 shows that in the sulfate-reduction zone of Sites 888 and 891 (Fig. 2), the $\delta^{13} \mathrm{C}$-DIC values of $\sim-20$ to $-26 \%$ are strongly depleted in ${ }^{13} \mathrm{C}$ relative to the overlying seawater $\left(\delta^{13} \mathrm{C}\right.$-DIC $\sim 1 \%$ ). In comparison, the sulfate-depleted sediments deeper in Sites 888 and 891 are more enriched in ${ }^{13} \mathrm{C}$ $\left(\delta^{13} \mathrm{C}\right.$-DIC $=-18$ to $0 \%$; Fig. 6) than in the sulfate zone. Comparing the same sediment depth intervals at Sites $889 / 892\left(\delta^{13} \mathrm{C}\right.$-DIC $=-2 \%$ to $+28 \%$ ) with Sites $888 / 891$ further reveals the dramatic difference between the $\delta^{13} \mathrm{C}$-DIC in sediments with and without sulfate (Fig. 6).

In the sulfate zone of Sites 888 and 891 , the increase in alkalinity related to the remineralization of organic matter and consumption of sulfate corresponds to the shifts in $\delta^{13} \mathrm{C}$-DIC to more negative values. This ${ }^{12} \mathrm{C}$ shift is due to the enrichment of the interstitial fluid with ${ }^{12} \mathrm{C}$ depleted bicarbonate from remineralized organic matter $\left(\delta^{13} \mathrm{C}_{\mathrm{org}}\right.$ $\approx-24 \%$ ). The resultant $\delta^{13} \mathrm{C}$-DIC is the simple mass balance of the $\delta^{13} \mathrm{C}$-DIC in the overlying water column $\left(\delta_{w}\right)$ with that released and added by diagenesis $\left(\delta_{\circ}\right)$, that is,

$$
\delta^{13} \mathrm{C}-\mathrm{DIC}=\mathrm{m}_{1}\left(\delta_{\mathrm{w}}\right)+1-\mathrm{m}_{1}\left(\delta_{\mathrm{o}}\right)
$$

where the mass fraction, $\mathrm{m}_{1} \leq 1$. 


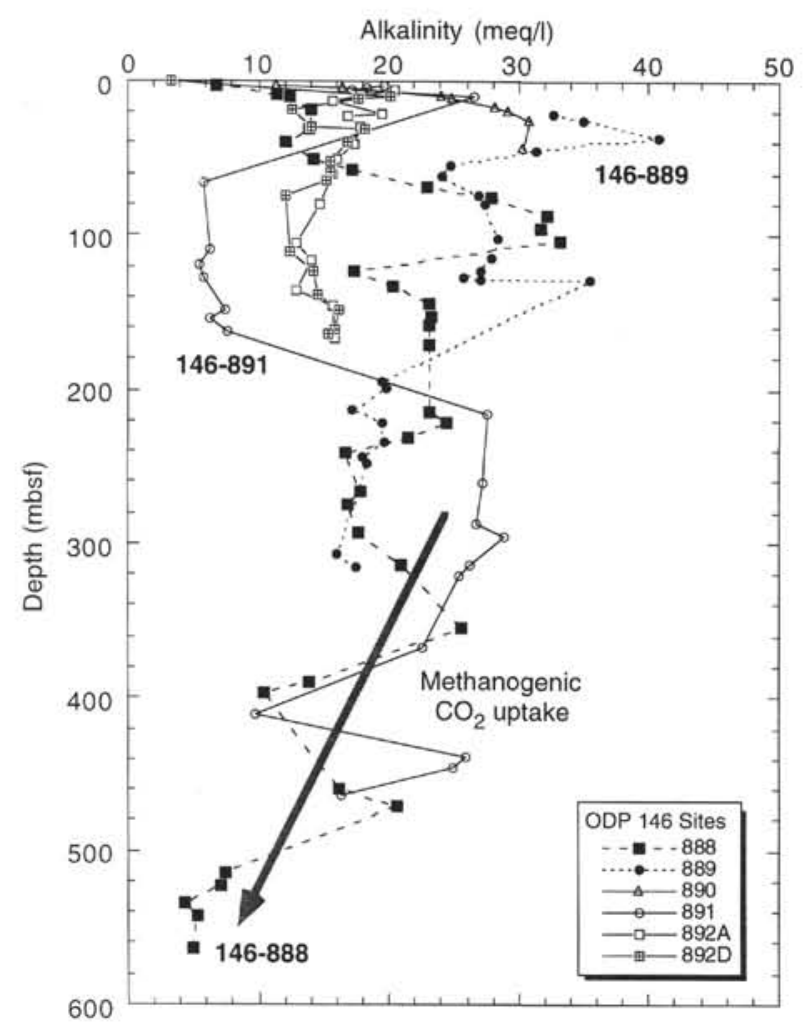

Figure 5. Depth distributions of total alkalinity in the interstitial fluids of Leg 146. Decrease in alkalinity at depth is due to methanogenic uptake of bicarbonate.

Well below the depth where sulfate is exhausted, $(>20 \mathrm{mbsf}$ in Sites 889 and $892 ;>210$ mbsf in Sites 888 and 891) the decrease in alkalinity (Fig. 5) is tracked by an enrichment of the dissolved inorganic carbon in ${ }^{13} \mathrm{C}$ (Fig. 6). This shift in $\delta^{13} \mathrm{C}$-DIC is due to the kinetic isotope effects associated with the methanogenic fermentation of bicarbonate, which preferentially utilizes ${ }^{12} \mathrm{C}$-DIC over ${ }^{13} \mathrm{C}$-DIC, as discussed below. At Sites 889 and 892 , where sulfate exhaustion and methanogenesis is close to the sediment surface, extreme ${ }^{12} \mathrm{C}$ DIC depletions, up to $+28 \%$, are observed.

The extremely ${ }^{12} \mathrm{C}$-DIC-enriched values at the sulfate-methane interface at Site $888(\sim 200-220 \mathrm{mbsf})$ are due to the oxidation of isotopically light, i.e., ${ }^{13} \mathrm{C}$-depleted bacterial methane. This is discussed in detail below.

\section{Methanogenesis}

Significant accumulations of methane are first observed at all sites only when the dissolved sulfate is exhausted by sulfate-reducing bacteria. In the sulfate-free sediments, methane concentration increases rapidly. Figure 7 depicts this well-known microbiological ecologic or diagenetic succession (e.g., Claypool and Kaplan,1974). In the uppermost 210 and 220 mbsf at Sites 888 and 891 , where dissolved sulfate is present (Fig. 2), the headspace methane is less than $10 \mathrm{ppmv}$. Within a sediment interval of $\sim 20 \mathrm{~m}$, just beneath the base of the sulfate reduction zone ( 210 to $230 \mathrm{mbsf}$ ), the headspace methane rises 4 orders of magnitude to $\sim 5 \mathrm{vol} \%$. At Sites 889,890 , and 892 , where sulfate removal is much shallower, the headspace methane accumulations increase rapidly to $10 \mathrm{vol} \%$ within the first $20 \mathrm{mbsf}$ of the sediment surface.

There is a remarkable consistency in the depth distribution of methane between all the sites (Fig. 7). Beneath the sulfate zone, it is interesting to observe that the headspace methane concentration at all

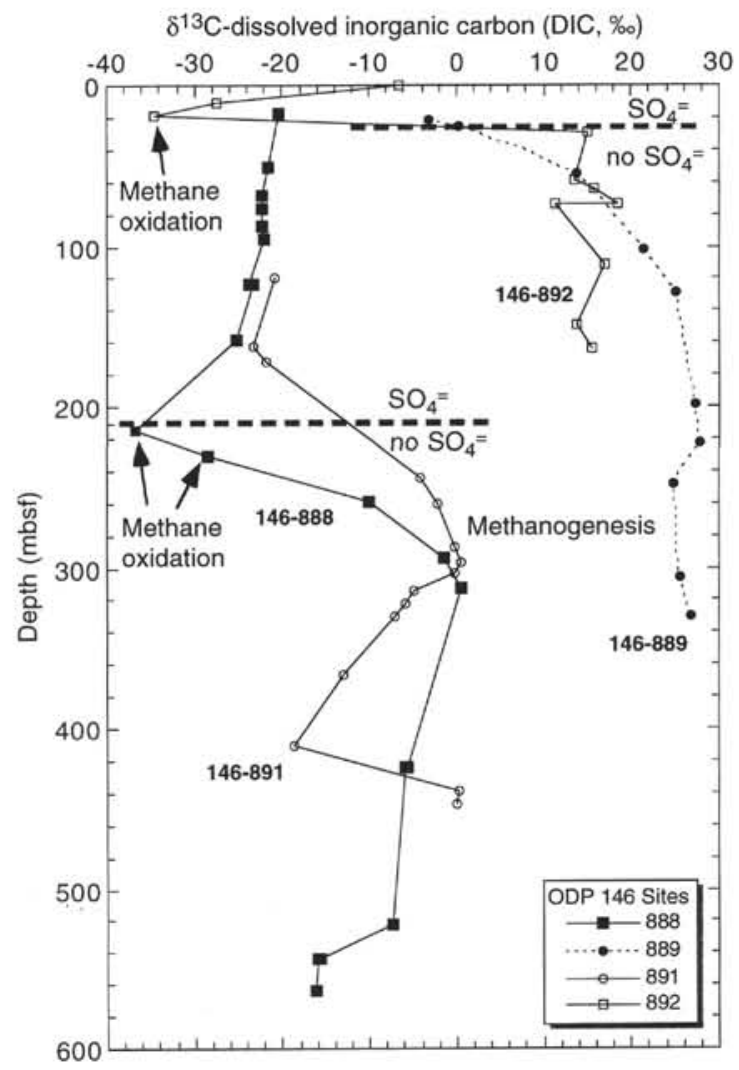

Figure 6. Depth distributions of $\delta^{13} \mathrm{C}_{\mathrm{DIC}}$ in the interstitial fluids of Leg 146. Dashed line indicates depth at which dissolved $\mathrm{SO}_{4}{ }^{2-}$ is exhausted at Sites 888 and 891. At Sites 889 and 892, sulfate is at or below detection limit below the uppermost $20 \mathrm{mbsf}$. The profiles represent the mixture of isotope signals due to organic matter remineralization, methanogenesis, and methanotrophy.

sites actually decreases regularly and uniformly with increasing depth. This is not due to a decrease in methane generation or accumulation; rather, this decrease is caused by the appearance and increasing importance of higher alkanes (ethane through hexane) in the deeper sections. Essentially, the partial pressure of methane is dropping by increasing dilution with the other hydrocarbon gases. These higher hydrocarbons are the result of thermogenic processes.

It is important to note that because of the analytical design, these methane gas values can only be regarded as relative concentrations. Pressure drop from hydrostatic deloading on core recovery causes gases to exsolve if oversaturated and expand if there is a free gas phase. Much of this free phase gas will be lost during sampling. Because of the high internal gas pressure in the liners of gassy cores, the liners were drilled to release pressure, end-caps were sometimes forced off, and in a few cases the liners failed. The high partial pressure of methane exsolving from the gassy cores is reflected in the Vacutainer samples, wherein methane constituted up to $99.8 \mathrm{vol} \%$ (see Westbrook, Carson, Musgrave, et al., 1994, "Site 888 " chapter, table 7; "Site 889" chapter, table 9; "Site 891" chapter, table 6; "Site 892" chapter, table 8 ). This mode of sampling and analysis can provide only minimum estimates of the gas present in a sample and cannot account for gases lost during core recovery. However, interstitial fluids that are undersaturated with methane at the surface can safely be assumed also to be undersaturated at depth.

The bacterial sources and contributions to the methane occurrences are confirmed by several lines of evidence. First, the high concentration of gas is an indicator of intense production. Although this could also be accounted for by upward migration or seepage of ther- 


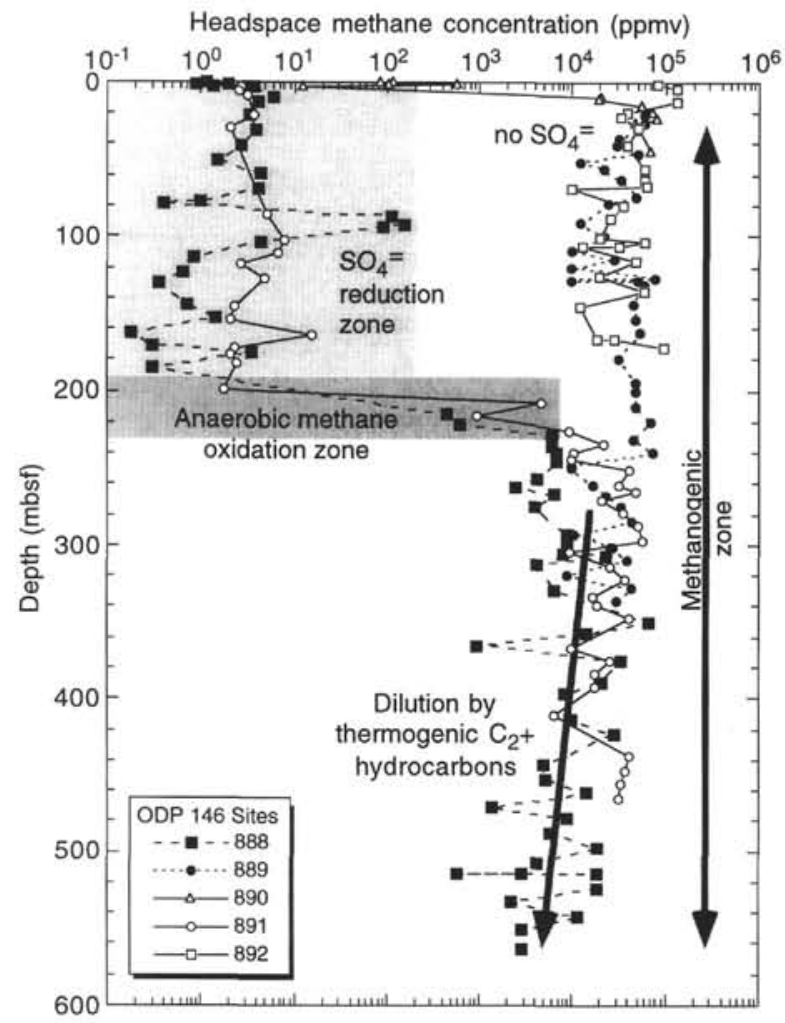

Figure 7. Depth distributions of headspace methane in the sediments of Leg 146. Sites 888 and 891 are dramatically different from Sites 889 and 892 in the sulfate reduction zone, but are similar at greater depth due to intensive methanogenesis and the admixture of thermogenic hydrocarbon gases.

mogenic gas, the low amounts of higher hydrocarbons in the upper sections, (e.g., $\mathrm{C}_{1} / \mathrm{C}_{2+}>10^{5}$ in Sites 888 and 889 ) point to a bacterial origin. Molecular fractionation of upwardly diffusing thermogenic gas (e.g., preferential methane diffusion) could lead to the "dry gas" signature, but this can be ruled out in concert with the isotope evidence.

The carbon-isotope ratio of methane is a more conclusive tool to characterize the possible sources of the hydrocarbons. Beneath the zone of sulfate reduction, the Vacutainer analyses of $\delta^{13} \mathrm{C}-\mathrm{CH}_{4}$ show methane strongly depleted in ${ }^{13} \mathrm{C}$. For example, at Sites 889 and 892 with sediments richer in organic matter, the near-surface $\delta^{13} \mathrm{C}-\mathrm{CH}_{4}$ is $-65 \%$ o to $-84 \%$ o (Fig. 8). These $\delta^{13} \mathrm{C}-\mathrm{CH}_{4}$ values are typical and diagnostic of methanogenesis (e.g., Claypool and Kaplan 1974; Whiticar et al., 1986). Similarly, at Sites 889 and 892 , the $\delta^{13} \mathrm{C}-\mathrm{CH}_{4}$ of the total gas analyses in the near-surface samples range from $-55 \%$ to $-66 \%$ o (Fig. 8). At Site 888, the methanogenic isotope signature dominates the total gas at the sulfate zone base $\left(\delta^{13} \mathrm{C}-\mathrm{CH}_{4}\right.$ of $-50 \%$ to $-60 \%$; Fig. 8). Although methanogenesis is clearly operating at Site 891, (e.g., $\delta^{13} \mathrm{C}-\mathrm{CH}_{4}$ of $-64 \%$ at $439 \mathrm{mbsf}$ ), the isotope data in the 300 400 mbsf interval indicate the presence of thermogenic gas.

Methanogenesis in marine sediments proceeds essentially by the $\mathrm{CO}_{2}$ reduction fermentative pathway. The carbonate reduction pathway can be represented by the general reaction

$$
\mathrm{CO}_{2}+8 \mathrm{H}^{+}+8 \mathrm{e}^{-} \rightarrow \mathrm{CH}_{4}+2 \mathrm{H}_{2} \mathrm{O}
$$

The rationale for this interpretation has been treated extensively elsewhere (e.g., see Whiticar, in press, for references ), but it is consistent with numerous results from other comparable DSDP (e.g., Claypool and Kaplan, 1974; Whiticar and Faber, 1987) and ODP sites (e.g., Whiticar and Faber, 1989; Kvenvolden and Kastner,

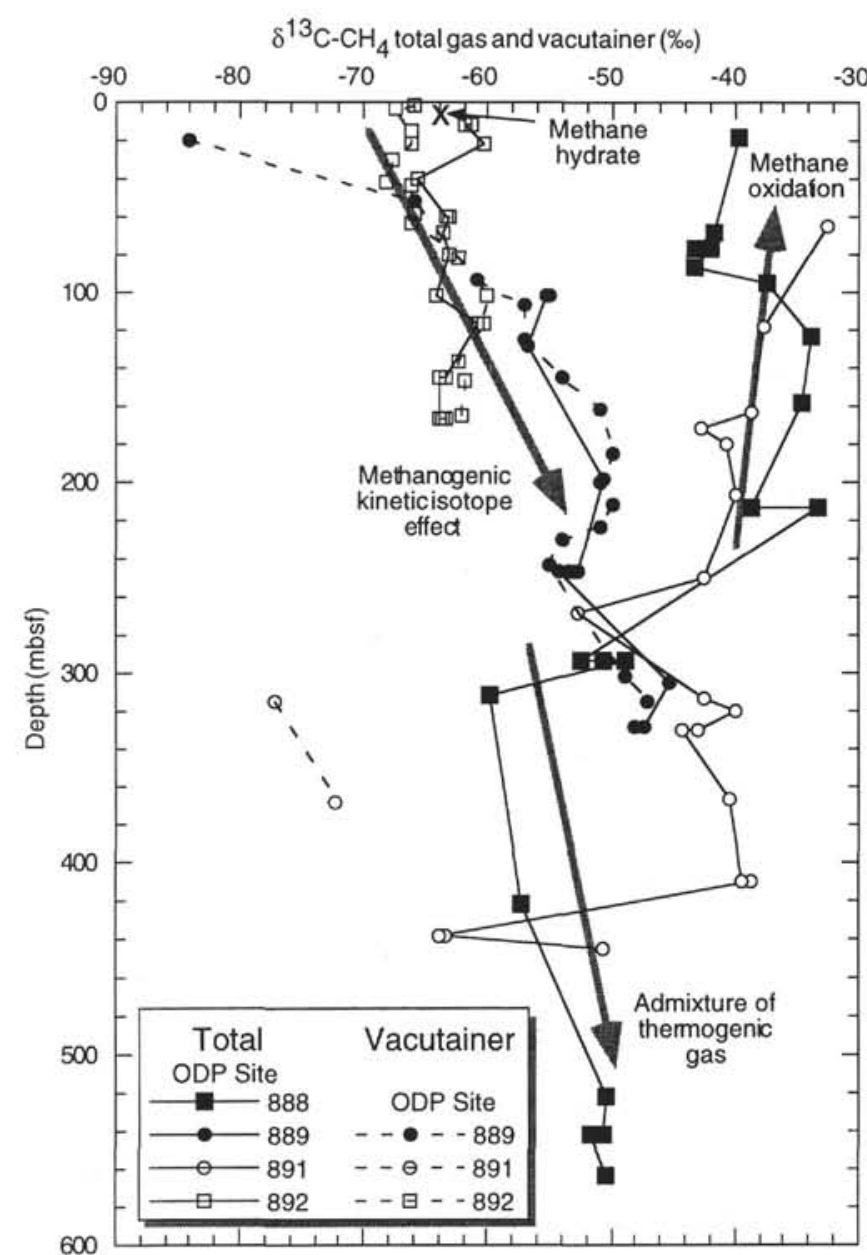

Figure 8. Depth distributions of $\delta^{13} \mathrm{C}_{\mathrm{CH} 4}$ in the Vacutainer methane and total gas methane samples of Leg 146. In the sulfate reduction zone of Sites 888 and 891 , the kinetic isotope effect of methane consumption enriches the residual methane in ${ }^{13} \mathrm{C}$. The ${ }^{12} \mathrm{C}$-enriched methane from methanogenesis at Sites 889 and 892 is diluted at depth by the admixture of thermogenic methane. The $\delta^{13} \mathrm{C}_{\mathrm{CH} 4}$ of the methane in the gas hydrates at Site 892, also shown, confirm a bacterial origin of the clathrated gas (Hovland and Whiticar, this volume).

1990). Briefly, the preformed organic substrates such as acetate or formate are effectively consumed by the SRBs in the sulfate zone. In marine systems, these substrates are thus generally not available to methanogens, as would be the case in freshwater environments. SRBs outcompete the methanogens for these compounds. Some methanogenesis may occur in the sulfate zone via non-competitive substrates such as trimethylamine (TMA) or dimethylsulfide (DMS), but this is (1) very limited and (2) the methane produced in this zone would be anaerobically consumed and recycled. Carbonate reduction does not proceed extensively in the sulfate zone and this is thought to be due to competition for available hydrogen (e.g., Daniels et al., 1980). Again, the SRBs and acetogens outcompete the methanogens. These microbiological constraints restrict the ecologic niche of methanogenesis.

Bicarbonate utilization by methanotrophs partly explains the decrease in alkalinity with depth at all sites beneath the zone of sulfate reduction (Fig. 5). Extensive precipitation of carbonate was not observed and it is not likely that this has contributed significantly to the drop in dissolved bicarbonate. 
Methanogenesis is associated with a kinetic isotope effect (KIE) that sees preferential conversion of isotopically light substrates, i.e., ${ }^{12} \mathrm{C}$-bicarbonate over ${ }^{13} \mathrm{C}$-bicarbonate to methane (Whiticar et al., 1986). This fractionated utilization of bicarbonate leads to isotope partitioning between the substrate reservoir (DIC) and the product reservoir $\left(\mathrm{CH}_{4}\right)$. This carbon isotope effect is predictable and, for methanogenesis via the $\mathrm{CO}_{2}$ reduction pathway, the KIE is between $60 \%$ and $80 \%$.

Figure 9 illustrates the relative magnitudes of isotopic offset between the bicarbonate $\left(\delta^{13} \mathrm{C}_{\mathrm{DIC}}\right)$ and methane $\left(\delta^{13} \mathrm{C}_{\mathrm{CH}}\right)$ pools, according to the equation (Whiticar et al., 1986):

$$
\alpha_{\text {DIC-CH }}=\left(\frac{\delta^{13} C_{\text {DIC }}+10^{3}}{\delta^{13} C_{\mathrm{CH} 4}+10^{3}}\right)
$$

The DIC- $\mathrm{CH}_{4}$ carbon isotope discrimination for the main zone of methanogenesis at Sites 889 and $892\left(\alpha_{\text {DIC-CH4 }}\right)$ ranges between 1.08 and 1.09. This indicates that the bacterial methane formation is present and that the formation pathway is carbonate reduction throughout both holes.

Isotopic fractionation or discrimination resulting from KIEs can be described by Rayleigh distillation relationships. The isotope ratio of the remaining reactant pool (e.g., a generating kerogen) that is being depleted in the lighter isotope can be approximated by

$$
\mathrm{R}_{\mathrm{r}} / \mathrm{R}_{\mathrm{o}}=f^{(1 / \alpha-1)} \text {, }
$$

and the progressive isotopic shift of the cumulative product pool (e.g., methane accumulation) by

$$
\mathrm{R}_{\Sigma} / \mathrm{R}_{\mathrm{o}}=\left(1-f^{(1 / \alpha-1)}\right) /(1-f),
$$

where $\mathrm{R}$ is the isotope ratio of the initial reactant $\left(\mathrm{R}_{\mathrm{o}}\right)$, the residual reactant at a specified time $\left(R_{r}\right)$, and the cumulative product $\left(R_{\Sigma}\right)$, respectively (e.g., Claypool and Kaplan, 1974). The fraction of the reactant remaining is $f$, and $\alpha$ is the isotope fractionation factor for the conversion of the reactant to the product. As a consequence of

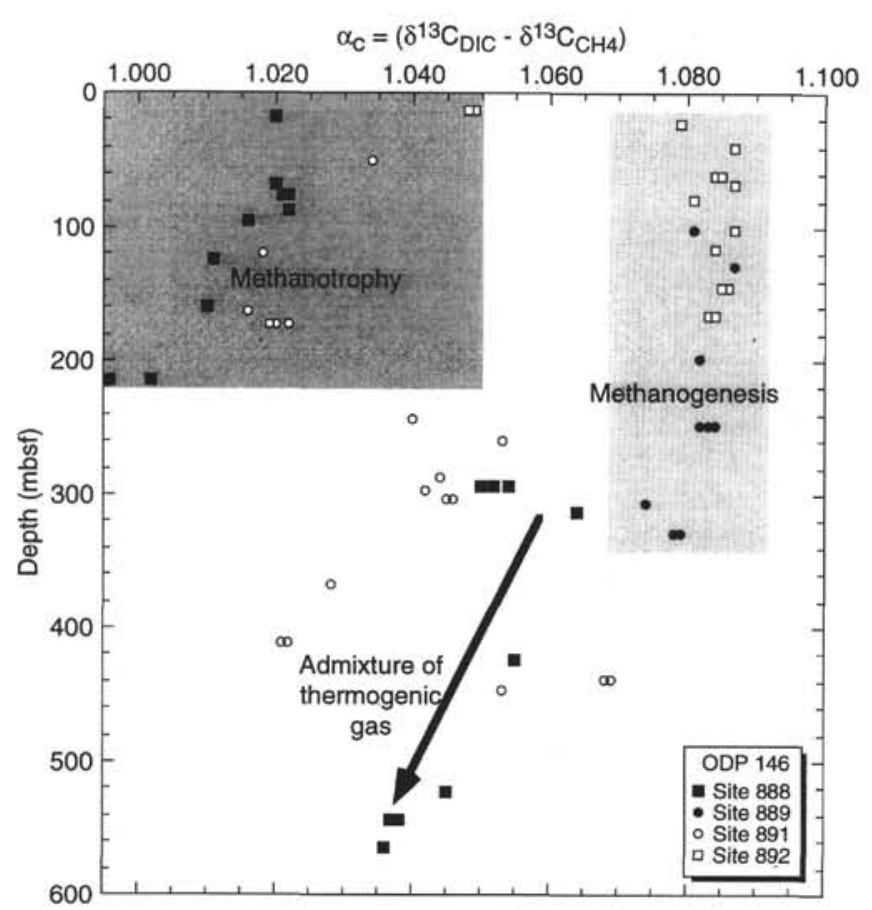

Figure 9. Depth plot of carbon isotope fractionation factors $\left(\alpha_{\text {DIC-CH4 }}\right)$ caused by methanogenesis and methanotrophy (Eq. 4). continued fractionation due to methanogenesis, the $\delta^{13} \mathrm{C}_{\mathrm{DIC}}$ becomes enriched in ${ }^{13} \mathrm{C}$ progressively with depth at all of the Leg 146 sites (compare Figs. 6 and 8). This shift tracks the decrease in alkalinity observed in Figure 5. As the DIC pool becomes isotopically enriched in ${ }^{13} \mathrm{C}$, subsequent methanogenesis will also generate methane enriched in ${ }^{13} \mathrm{C}$, as seen in the headspace gas, and, to some extent, in the total gas (Fig. 8).

\section{Methanotrophy}

The spatial separation of methane and sulfate, documented at all Leg 146 sites, is caused by a combination of microbial competitive exclusion discussed above and microbial methane consumption (essentially the back reaction of Eq. 3). The steep methane concentration gradient at the base of the sulfate zone and onset of methanogenesis, illustrated in Figure 7, cannot be maintained without an additional methane loss term (e.g., Reeburgh, 1976; Martens and Berner, 1977). Methane diffusing upward along the gradient from the zone of methanogenesis would quickly redistribute methane into the sulfate zone. This is not observed because of very effective methanotrophy, i.e., anaerobic methane oxidation at the base of the sulfate zone. At Sites 888 and 891 , this methane oxidation zone is $<20 \mathrm{~m}$ thick and is highly efficient in removing methane advecting or diffusing upward (also see Cragg et al., this volume).

Analogous to methanogenesis, the process of methanotrophy is also associated with a KIE and can be described by Rayleigh fractionation relationships (Eqs. 5, 6). Again, ${ }^{12} \mathrm{C}$ is preferentially used, in this case methane is the reactant pool, and isotopically light bicarbonate is produced. At Sites 888 and 891 , the dramatic drop in methane concentration moving upward in the hole into the sulfate zone, at around $210 \mathrm{mbsf}$, is tracked by a commensurate shift to heavier $\delta^{13} \mathrm{C}$ $\mathrm{CH}_{4}$ values as heavy as $-32 \%$ (Figs. 7,8 ). The local ${ }^{12} \mathrm{C}$-DIC enrichment is also readily observed at all of the Leg 146 sites (Fig. 6), but is particularly well demonstrated at Sites 888 and 891 .

The isotope effect for anaerobic methane consumption is less than that for methanogenesis, and $\alpha_{\text {DIC-CH4 }}$ ranges between 1.01 and 1.03 (Whiticar and Faber, 1986). Figure 9 depicts this difference in the KIEs for methanogenesis and methanotrophy.

Another consequence of methanotrophy is carbonate precipitation. This is often not distinctly recognized as an increase in sedimentary carbonate; however, a shift in dissolved $\mathrm{Ca}^{2+}$ or $\mathrm{Mg}^{2+}$ can frequently indicate such precipitation (e.g., Site 891 at $200 \mathrm{mbsf}$; see Westbrook, Carson, Musgrave, et al., 1994, "Site 891" chapter, fig. $38)$.

\section{Microenvironments}

Site 888 (87-103 mbsf; Fig. 10) exhibits a curious diagenetic microenvironment that serves as an example of the diagenetic interplay between the microbial communities active in sulfate reduction, methanogenesis and methanotrophy. In this narrow, 20-m interval, sulfate is exhausted locally, leading to elevated alkalinity and the commencement of methanogenesis in this interval. On either side of this depth interval, dissolved sulfate is present at levels $>10 \mathrm{mM}$, thus describing a non-steady-state environment. The explanation of this situation is unclear. One suggestion is a repeated stratigraphic section, (i.e., an overlying slump block), but sedimentologically there is no unconformity or significant break in the turbidite sequence to support this. Another possibility was that a seepage of methane had laterally penetrated the section. Locally then, the sulfate would be consumed in the oxidation of the methane, leading to the observed sharp rise in alkalinity. A sympathetic rise in the other nutrients was not documented. This may indicate that any lateral flow came from or through sediments with similar interstitial fluid nutrient concentrations, unless the methane further stimulated normal organic matter remineralization. Furthermore, the newly added bicarbonate should be isotopically lighter than the adjacent remineralized DIC due to the ${ }^{12} \mathrm{C}$-rich methane source, but this too was not observed. Significantly 
Figure 10. Summary of diagenesis and microenvironments at Site 888.

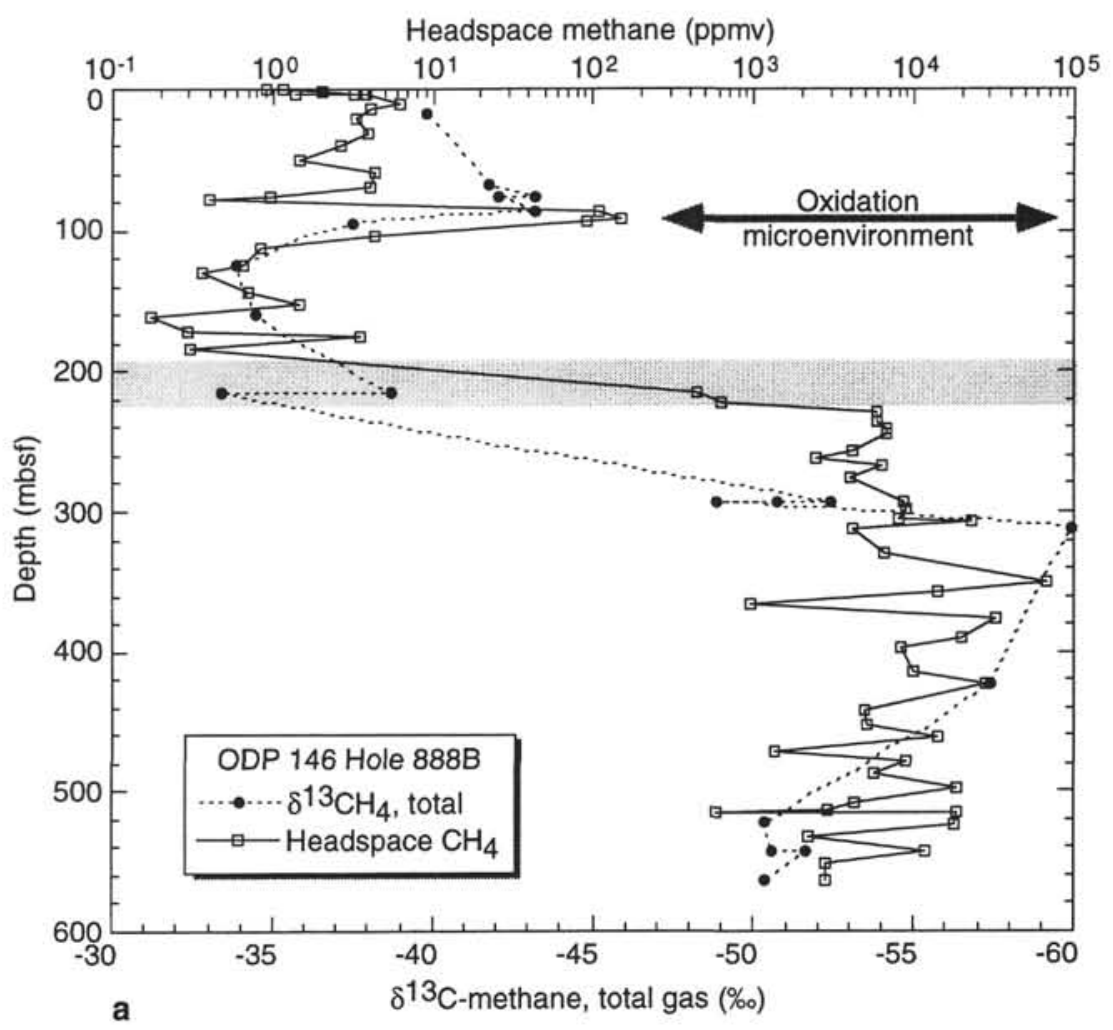

elevated bacterial counts of methanogens and rates of methane oxidation are reported for this interval (Cragg et al., this volume). The distribution pattern of reactant and products, their isotopes, and the microbial counts suggest a non-steady-state condition, as perhaps expected from a pulsed lateral flow injection.

\section{Summary}

Bacterial activity is a significant diagenetic force in all the Leg 146 sites. The primary processes are sulfate reduction by SRBs, methanogenesis by methanogens, and anaerobic microbial methane oxidation. Figure 10 summarizes the intricate relationships between sulfate, alkalinity, and methane using Site 888 as model. Sulfate reduction diagenetically precedes methanogenesis. At this diagenetic interface, anaerobic methane consumption effectively filters out any upwardly mobile methane. As a result of established KIEs, the bacterial methane is depleted in ${ }^{13} \mathrm{C}$ in the methanogenic zone, but the minor residual methane in the sulfate zone is enriched in ${ }^{13} \mathrm{C}$.

\section{CATAGENESIS AND FLUID FLOW AT THE CASCADIA MARGIN}

Thermogenic hydrocarbons are present in all of the Leg 146 sites. These are derived from the thermal reorganization and cracking of organic matter. It is not surprising that thermogenic hydrocarbons are present, considering the higher than normal heat flow regime associated with the young age and therefore hotter condition of the underlying oceanic crust. We have reported thermogenic hydrocarbons in the sediments of numerous analogous DSDP and ODP settings (e.g., Whiticar and Faber, 1987, 1989; Whiticar and Suess, 1990). However, the occurrence of thermogenic hydrocarbons in 146 is not uniform or homogeneous. In this regard, the VIM sites were very different from the COM sites.
The presence of thermogenic hydrocarbons is recognized and confirmed by:

1. the appearance of higher hydrocarbon homologs, i.e., ethane through hexane $\left(\mathrm{C}_{2+}\right.$ fraction);

2. increase in $\mathrm{C}_{2+}$ fraction relative to methane; and

3. methane/stable-carbon isotope ratios.

Figure 11 shows the influence of thermogenic hydrocarbons on the molecular $\mathrm{C}_{1} / \mathrm{C}_{2+}$ ratios measured on the headspace samples from the four study areas. As mentioned earlier, $\mathrm{C}_{1} / \mathrm{C}_{2+}$ ratios $>10^{5}$ are typical of methanogenesis by $\mathrm{CO}_{2}$ reduction in marine systems. Bacterial gas can and does have $C_{1} / C_{2+}$ ratios as low as 100 , but these are frequently associated with humic- or methyl-fermentative methanogenesis typical of freshwater settings.

\section{Thermogenic Gases and Fluid Flow at VIM}

At Site 888 , bacterial methane dominates from 220 to $520 \mathrm{mbsf}$. The first occurrences of thermogenic hydrocarbons are below 520 mbsf (Fig. 10 and 11). In contrast, at Site 889 (Fig. 11), the influence of thermogenic gases extends up close to the surface and the sulfate zone $(<10 \mathrm{mbsf})$. The proportion of the thermogenic end-member of this two-component bacterial-thermogenic mixing increases gradually with greater depth reaching $\mathrm{C}_{1} / \mathrm{C}_{2+}$ values $<100$.

This admixture of thermogenic methane to the bacterial gas is also evident in the shift of $\delta^{13} \mathrm{C}_{\mathrm{CH} 4}$ to heavier values in the Vacutainer and total gas samples (e.g., from $-65 \%$ to $-45 \%$; Fig. 8). This mixture of the two hydrocarbon gas types is best visualized in Figure 12 which compare the molecular and stable isotope ratios of the Vacutainer and total gases. Estimations of the actual bacterial-thermogenic mixing proportions cannot be made, because this would depend on the assumption of the molecular and isotope ratios of the thermogenic endmember. 


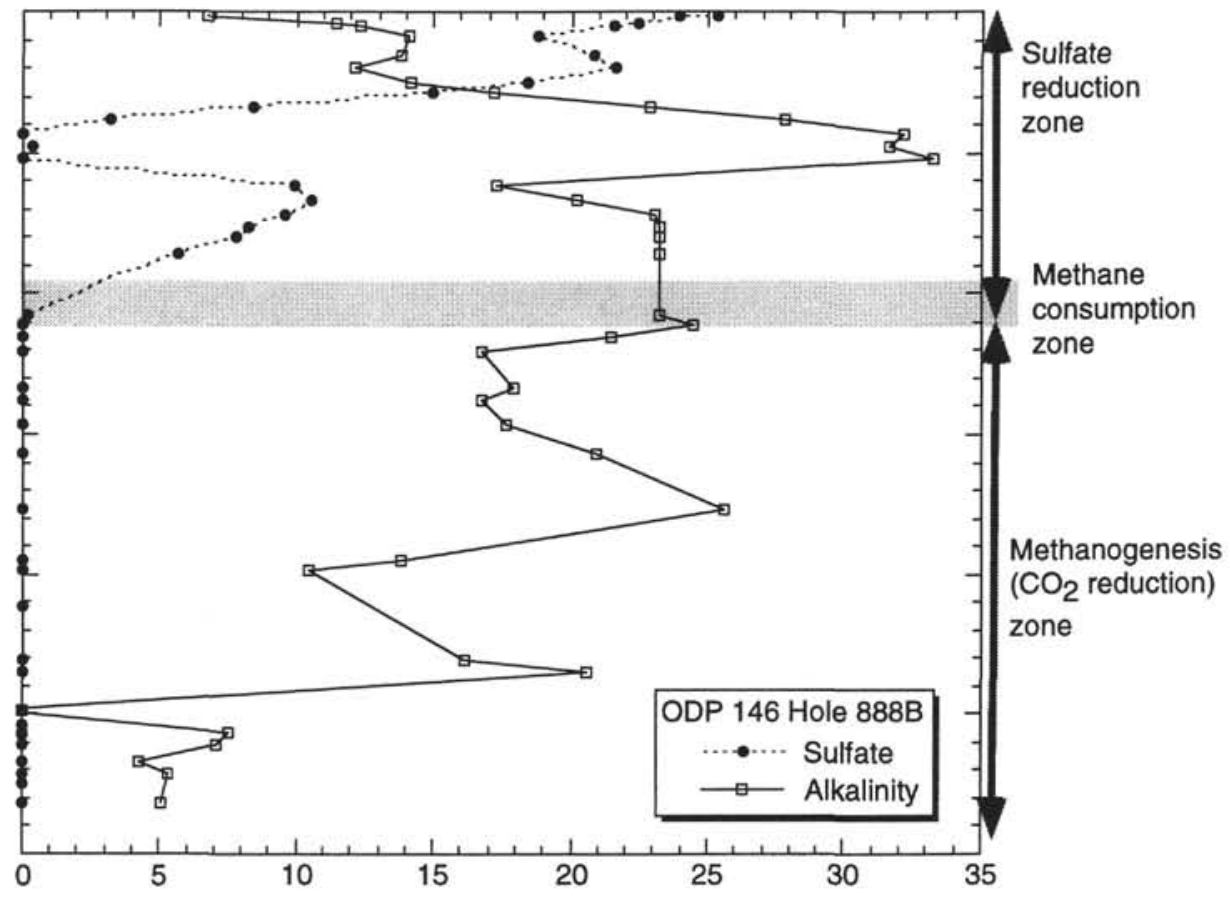

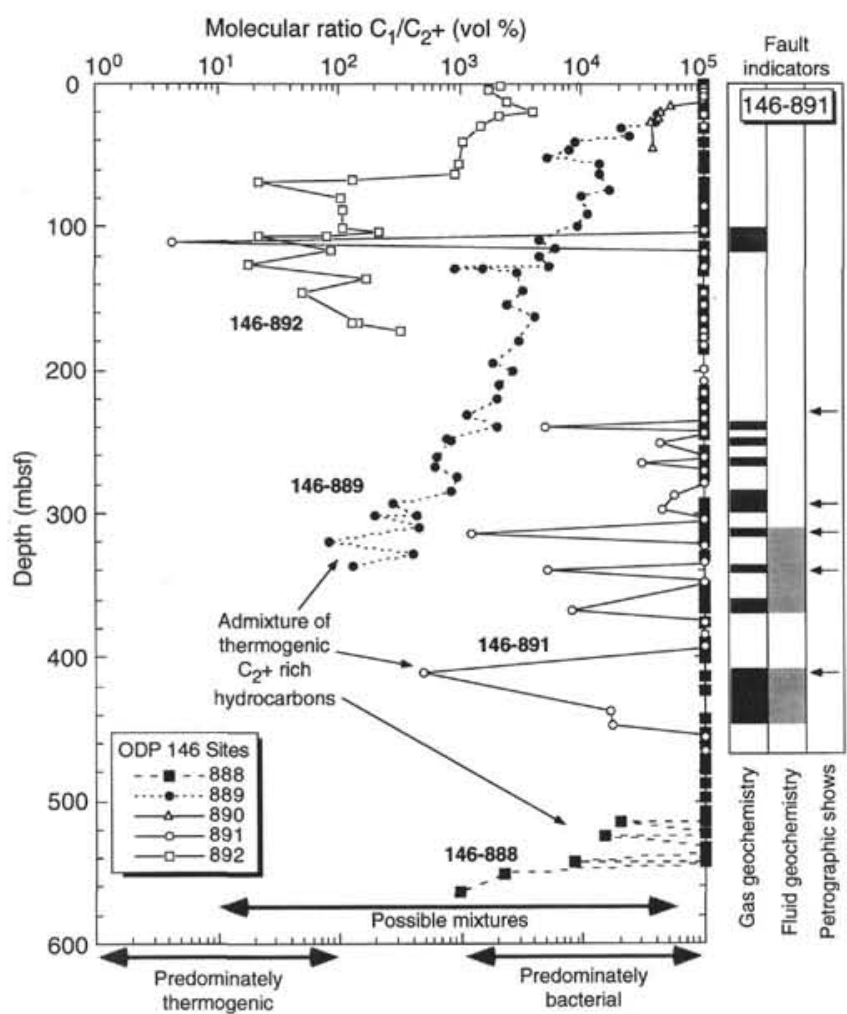

Figure 11. Depth distributions of $C_{1} / C_{2+}$ in headspace gas of Leg 146. The shift to lower ratios indicates the admixture of thermogenic hydrocarbons. The correlation is shown for Site 891 between the gas, fluid, and petrographic indicators of faults.

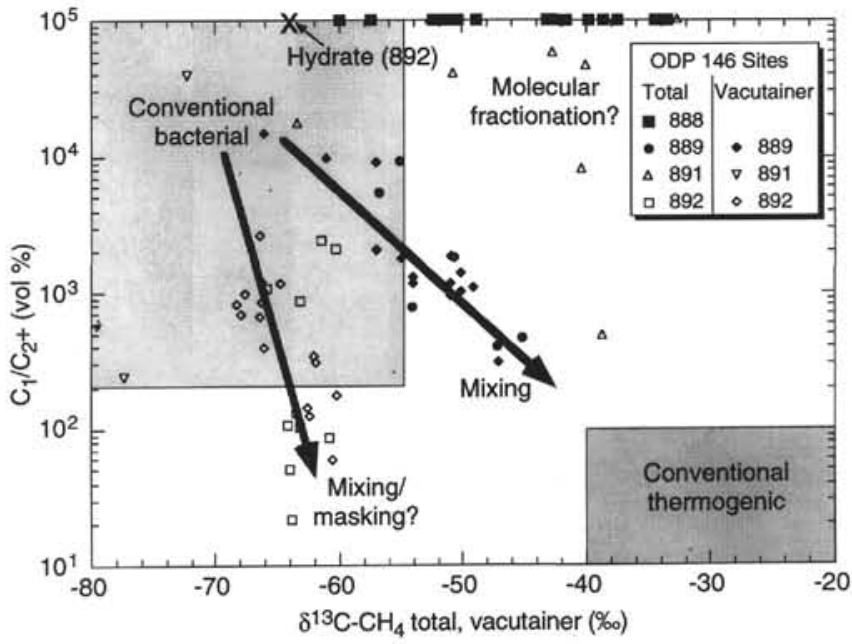

Figure 12. Characterization of Vacutainer and total hydrocarbon gases by molecular and methane stable carbon isotope ratios.

The usefulness of the $\mathrm{C}_{1} / \mathrm{C}_{2+}$ parameter to characterize hydrocarbon sources and secondary effects, such as mixing, is readily apparent in Figure 12. Based solely on the $\delta^{13} \mathrm{C}_{\mathrm{CH} 4}$ at Site 888 , one could misinterpret the isotopically-heavy methane values as being from a thermogenic source. However, the $C_{1} / C_{2+}>10^{5}$ clearly identifies the gas as being of bacterial nature but subjected to extensive oxidation. This interpretation is also consistent with the location of the gas and the related geochemistry.

With geothermal gradients of $68^{\circ} \mathrm{C} / \mathrm{km}$ and $54^{\circ} \mathrm{C} / \mathrm{km}$, the bottom hole temperatures at Sites 888 and 889 are $40^{\circ} \mathrm{C}$ and $21^{\circ} \mathrm{C}$ respectively. Certainly these are far too cold for catagenesis and thermogenic hydrocarbon formation. Based on these geothermal gradients, a min- 
imum depth for thermogenic hydrocarbon generation would be in excess of $1 \mathrm{~km}$. This suggests that the higher hydrocarbons have migrated vertically into the sediments of Sites 888 and 889 , probably by diffusional and normal compaction advectional processes. The uniform sedimentation at the VIM has likely promoted this situation and there is no evidence for focused fluid flow based on the hydrocarbon character or distributions.

\section{Thermogenic Gases and Fluid Flow at COM}

In contrast to the VIM sites, the fracture-controlled settings at the COM Sites 891 and 892 show a strong influence of fluid or gas flow. Thermogenic hydrocarbons are present, as plotted in Figure 11, but their distribution is erratic and essentially maps the locations of the faults and fractures in both Sites 891 and 892 .

In Site 891, the first indication of thermogenic gas intrusion into the sediments is at $110 \mathrm{mbsf}$ (Fig. 11), and this corresponds to a chemical anomaly as well as shown on the side bar of Figure 11. Below 240 mbsf, repeated incursions of thermogenic gas are encountered. Although core recovery was very poor at Site 891 , several major and minor fracture and thrust fault zones are identified (see Westbrook, Carson, Musgrave, et al., 1994, "Site 891" chapter, fig. 21). Based on the structural geology, the first fractured domain starts at 198 mbsf. Faults in Site 891 are reported at 225, 263, and 295 mbsf, between 310 and $360 \mathrm{mbsf}$ and again between 410 and $446 \mathrm{mbsf}$, corresponding closely to the intervals with noticeable $\mathrm{C}_{2+}$ increases (Fig. 11). The $C_{2+}$ highs at 314,339 , and 411 mbsf also corresponded to the intervals where the petroliferous odors were most intense, and higher $\mathrm{CO}_{2}$ levels were recorded. This may suggest that the $\mathrm{CO}_{2}$ is thermally derived, either from the release of carboxyl groups during the maturation of organic matter, or from inorganic sources, including carbonate decomposition. Chloride at Site 891 also increased sharply at 200 mbsf (Westbrook, Carson, Musgrave, et al., 1994, Site 891 chapter, fig. 38) and continued to increase with depth. The interstitial fluid chemistry also indicates significant fluid flow around 216, 250-260, and between $300-320 \mathrm{mbsf}$ (Fig. 11). The $\delta^{13} \mathrm{C}_{\mathrm{CH} 4}$ of the total gas at Site 891 is relatively variable with depth, and this reflects the alternation or interfingering of bacterial gas and thermogenic gas-dominated sections, as plotted in Figure 8.

Although the holes at Site 892 are much shallower, the data collected share some similarities with Site 891. Again, both bacterial and thermogenic gases are present. Below $73 \mathrm{mbsf}$, the thermogenic gases appear as geochemical intrusions or $\mathrm{C}_{2+}$ incursions (Fig. 11). The interstitial fluid chemistry supports the presence of fluid flow in the deeper section of the hole. The isotopic expression of this mixing between bacterial and thermogenic gas at Site 892 is not easily seen in the depth profiles (Fig. 8), but is possible in the $\delta^{13} \mathrm{C}_{\mathrm{CH} 4}-\mathrm{C}_{1} / \mathrm{C}_{2+}$ diagram of Figure 12. At Site 892, only a mild to strong fluorescence was encountered in the sediments. This is because of thermally generated aromatics and further supports the idea of fluid flow.

The geothermal gradients of $25^{\circ} \mathrm{C} / \mathrm{km}$ at Site 891 (a minimum estimate) and $51^{\circ} \mathrm{C} / \mathrm{km}$ at Site 892 are similar to VIM. Analogously, the sediments encountered in the holes are far too cold and young to have generated the thermogenic hydrocarbons encountered. The immature nature of the cored sediments is supported by the Rock-Eval and Geofina results (Westbrook, Carson, Musgrave, et al., 1994, "Site 891 " chapter, fig. 33 and "Site 892" chapter, fig. 43). Based on all of this evidence, the thermogenic hydrocarbons must be allochthonous and be derived from deeper, more mature sediments, probably $>1 \mathrm{~km}$ in depth.

The presence in both Sites 891 and 892 of the olefin, ethene, is most unusual. Because it is geologically unstable and can form by hydrothermal processes, it is a very interesting indicator of more rapid fluid flow and higher emplacement rates than at the VIM sites. The fractured geologic environment at COM is the logical explanation for this difference to the VIM.

\section{Summary}

Thermogenic hydrocarbons are ubiquitous at Leg 146 sites. Based on maturity and temperature considerations, these hydrocarbons could not have been generated in situ, and must have migrated into the shallower sections from more mature sediments, likely at greater depth. The emplacement of thermogenic hydrocarbons at COM is controlled by fractures and faults and is directly related to fluid flow and compaction at this accretionary prism. At VIM, thermogenic hydrocarbons migrate into the shallower sediments by diffusion rather than active fluid flow.

\section{HYDRATES AT CASCADIA MARGIN}

Direct observation and physical collection of hydrates during Leg 146 was limited to a few pieces recovered near the surface at Site 892. These were unexpected sulfide-rich hydrates occurring between $2-5$ mbsf and $<19$ mbsf. Deeper at Site 892 and possibly at Site 889 , the gas hydrates occur as macrocrystals, or as pellets. Due to the decrease in pressure and rise in temperature that the recovered core undergoes, these disseminated hydrates do not survive the transport from their in situ sedimentary position to the shipboard catwalk.

The major outstanding questions regarding the hydrates are:

1. what is the reason for the discrepancy between the seismic evidence for the depth of the hydrate, indicated by the bottomsimulating reflector (BSR) and the depth for the theoretical P$\mathrm{T}$ limit of hydrate stability;

2. is there a free gas phase beneath the BSR; and

3. what is/are the source(s) of the gas(es) in the hydrates?

\section{Hydrates at VIM Site 889}

At Site 889, the depth of the BSR is inferred to lie around 225 mbsf (Fig. 12), based on the migrated seismic two-way traveltime (276 ms TWT) calibrated by the sonic and VSP logs (Westbrook, Carson, Musgrave, et al., 1994; "Site 889" chapter, fig.102). Using the temperature gradient of $54^{\circ} \mathrm{C} / \mathrm{km}$ and a bottom-water temperature of $2.7^{\circ} \mathrm{C}$, the temperature at $225 \mathrm{mbsf}$ would be $14.9^{\circ} \mathrm{C}$, well within hydrate P-T stability field (Fig. 12). Extrapolation of the temperature-hydrostatic pressure gradients to greater depths, intersects the phase boundary for a pure methane-water hydrate at $260 \mathrm{mbsf}$ and $16.7^{\circ} \mathrm{C}$ (shown in Fig. 12), or $35 \mathrm{~m}$ deeper than the reported BSR. Using a methane-seawater phase boundary, the depth for the P-T compensated hydrate stability would move up to $228 \mathrm{mbsf}$, close to the observed BSR depth. At this P-T region, the temperature has a stronger influence on the hydrate stability than pressure. For example, moving along the methane-water hydrate P-T phase line, a 1-m change in depth corresponds to a 0.1 bar change in pressure and is approximately equivalent to a $0.012^{\circ} \mathrm{C}$ on the phase line. Considering the $0.054^{\circ} \mathrm{C} / \mathrm{m}$ geothermal gradient, the temperature effect is roughly five times the pressure effect in this depth range. Thus, it is predominantly the temperature gradient component, not the pressure gradient, of hydrate stability that in this particular situation causes and controls the hydrate to form and dissociate at specific depths. The influences of (1) additional gases, such as ethane, carbon dioxide, and nitrogen, (2) interstitial fluid chemistry, and (3) sediment matrix effects can also be significant controls on hydrate occurrence. The latter is poorly understood, and the former two are discussed below.

The depth discrepancy between the seismic BSR estimate of hydrate stability and the chemical phase boundary is made uncertain by the addition and presence of other gas species. Elevated concentrations of methane are found throughout the entire hydrate section (130-280 mbsf; Fig. 13) with an anomalously high value of 33,000 ppmv at $230 \mathrm{mbsf}$, just below the BSR. As noted above, it is possible 
that this $\mathrm{CO}_{2}$ is of thermogenic origin. $\mathrm{A} \mathrm{CO}_{2}$-methane-water hydrate is stable at higher temperatures or lower pressures than a pure methane-water hydrate and thus could not account for an upward translation of the hydrate stability field. Likewise, at constant temperature, a natural gas-water hydrate is stable at much shallower depths than a methane-water hydrate (Marshall et al., 1964). For example, a 10\% addition of ethane to a pure methane hydrate at $15^{\circ} \mathrm{C}$ would shift the phase boundary from 140 bar to 75 bar (Katz et al., 1959). Nitrogenwater hydrate, on the other hand, is much less stable than a methanewater hydrate.

Another possible reason for the depth difference between the BSR and hydrate stability is a shortage of interstitial fluid. Hydrate will continue to form only if sufficient gas and water are available. Generally the focus in hydrates has been on the question of where the quantities of methane come from; however, if sufficient gas is present, then hydrate formation could continue until all the pore water is clathrated. Excess gas at this point could occur in the free gas phase. An argument for this case is the detection of a free gas phase by the VSP measurements below the BSR (231-243 mbsf, Westbrook, Carson, Musgrave, et al., 1994, "Sites 889 and 890 " chapter, fig. 102). The argument against this possibility in Leg 146 is that the hydrate formed is presumed to occupy only $\sim 8 \%$ of the pore space. This estimate is based only on direct temperature measurements of the sediments, as no hydrate was recovered (see discussion in Westbrook, Carson, Musgrave, et al., 1994, "Sites 889 and 890 " chapter, pp. 183-184).

Unfortunately the pressure core barrel deployments were not successful, so that no in situ gas, fluid, or core samples were available. Furthermore, as mentioned earlier, the gas measurement techniques typically used cannot detect or record gas concentrations higher than saturation at the surface P-T conditions of the shipboard catwalk where sampling is made. This is a major limitation in assessing the presence and nature of free-dissolved and clathrated gas in the subsurface.

The chloride concentration at Site 889 is very constant around 400 $\mathrm{mM}$ or about $70 \%$ of seawater below $180 \mathrm{mbsf}$ (Westbrook, Carson, Musgrave, et al., 1994, "Sites 889 and 890 " chapter, fig. 64). No significant trends were observed in or below the hydrate zone.

Westbrook, Carson, Musgrave, et al., (1994, p. 229) presented possible arguments for vertical migration of the hydrate stability field due to (1) glacial-interglacial oceanography and (2) sedimentation and accretionary uplift. During the last glacial period, sea level fell approximately $100 \mathrm{~m}$. The lowered hydrostatic pressure could destabilize the lowermost section of the hydrate, moving the stability field upward (to lower temperature). Similarly, accretionary uplift would translate the base of the hydrate zone upward. During glacial periods the bottom water temperature was $\sim-1.3^{\circ} \mathrm{C}$, i.e., $4^{\circ} \mathrm{C}$ colder than at present. As the colder temperature penetrated downward into the sediments during the glacial period, the effect would have been to displace the hydrate stability field deeper in the sediment column, i.e., opposite to that caused by the pressure drop due to the sea level change or accretionary uplift (Fig. 13). Provided the geothermal gradient remained the same, at $54^{\circ} \mathrm{C} / \mathrm{km}$, then the two effects would be opposite, but not offsetting. As mentioned, the temperature change has a greater impact. As a result, during glacial times, the hydrate stability field and the BSR would be approximately $70 \mathrm{~m}$ deeper than at present. Warming of the oceans during the interglacial period would cause the hydrate zone to move upward (Fig. 13). The gases released by this hydrate dissociation in the destabilized zone, between 295 and 225 mbsf (using the BSR as a reference), would then supersaturate the interstitial fluid, then rise upward until clathrated once again at the new depth for hydrate stability. This cryo-distillation would require a certain period of time for all the gas to be released to migrate upward and form hydrate. Perhaps a time lag could be an alternative explanation for the free gas at the base of the present BSR.

\section{Hydrates at COM Site 892}

At Site 892 , near-surface hydrogen sulfide-methane-water hydrates were encountered and sampled. The $\mathrm{H}_{2} \mathrm{~S}$ levels released on the external catwalk during the dissociation of these hydrates were high (Fig. 4) and of serious concern to the safety and well-being of the shipboard personnel. Although these $\mathrm{H}_{2} \mathrm{~S}-\mathrm{CH}_{4}$-hydrates were not expected, they are stable at the prevailing $\mathrm{P}-\mathrm{T}$ conditions. $\mathrm{H}_{2} \mathrm{~S}$ raises the hydrate formation temperature so that at the depth of discovery (69 bar hydrostatic pressure) a $10 \%$ addition of $\mathrm{H}_{2} \mathrm{~S}$ to the $\mathrm{CH}_{4}$-water hydrate would raise the stability to $21^{\circ} \mathrm{C}$ (e.g., Hitchon, 1974). Conversely, $\mathrm{H}_{2} \mathrm{~S}$-water hydrates are stable at $\sim 10 \mathrm{~m}$ at $0^{\circ} \mathrm{C}$. The implication of this is that $\mathrm{H}_{2} \mathrm{~S}$ hydrates should actually be common in reducing sediments with extremely high sulfide. Rapid dissociation may hamper their recognition in piston cores. For geochemical situations where the sulfide is not sufficient to saturate the interstitial water, the addition of methane can assist in the hydrate formation, cotrapping the $\mathrm{H}_{2} \mathrm{~S}$ in the hydrate cages. The fact that this reactive species has not reacted to iron monosulfides, despite the presence of iron, attests to the relative chemical inertness of the hydrate phase.

Repeated isotope analyses of the methane dissociated from the hydrates collected at the Site 892 surface produced $\delta^{13} \mathrm{C}_{\mathrm{CH} 4}$ of $-64 \%$ (Hovland and Whiticar, this volume). This is nearly identical to the $\delta^{13} \mathrm{C}_{\mathrm{CH} 4}$ of $-62 \%$ measured in the total gas and the $\delta^{13} \mathrm{C}_{\mathrm{CH} 4}$ of $-66 \%$ to $-68 \%$ in the Vacutainer samples (Fig. 14). These values indicate a bacterial origin for the methane in the hydrates. The most probable source of the $\mathrm{H}_{2} \mathrm{~S}$ is from bacterial sulfate reduction of the in situ dissolved sulfate.

Analogous to the VIM Site 889 , this site also had a large discrepancy of $47 \mathrm{~m}$ ( $35 \mathrm{~m}$ in 889 ) between the methane-water hydrate stability depth (120 mbsf) and the seismically-VSP inferred BSR at 73 mbsf (Fig. 14). Similar arguments for the depth difference apply to this site as are discussed for Site 889 above. The major distinctions of Site 892 to Site 889 are:

1. lower $\mathrm{CO}_{2}$ concentrations in Site 892;

2. significantly more $\mathrm{C}_{2}+$ hydrocarbons in the whole of Site 892 , but in particular between 68 and 165 mbsf (Fig. 14); and

3. temperature incursions in Site 892 that raise the temperature locally.

The presence of the higher hydrocarbons at Site 892 (Fig. 13) may serve to stabilize the natural gas-water hydrates despite the intrusions of warmer fluids. The higher hydrocarbons are clearly allochthonous gas, generated deeper in the prism. Thus, it appears that the surface hydrates at Site 892 ( 2 to $<19$ mbsf) are formed from diagenetic gases, but that the deeper hydrates have a significant component of thermogenic gas added.

\section{Summary}

Hydrates are present at both VIM and COM, but samples were recovered only from near-surface samples at Site 892 . The hydrates are not massive; rather, they must be macrocrystalline and disseminated within the pore spaces of the sediment. A rise in temperature and drop in pressure likely caused these hydrates to dissociate either during drilling or during core recovery before sampling on the catwalk.

Methane-freshwater hydrate phase models do not adequately describe the observed base of the hydrated stability field, as defined by the acoustic BSR evidence. The contribution and/or combination of other trace gases, salts, and sediments most probably influence the true hydrate stability.

At the VIM, the unfocused flow leads to more homogeneous hydrocarbon profiles, and the hydrates are essentially methane-water or methane-carbon dioxide-water. The COM methane hydrates are 
Figure 13. Summary depth plot of hydrate stability and distribution for Site 889.

strongly "contaminated" with hydrogen sulfide and higher hydrocarbons (Hovland and Whiticar, this volume). The latter are associated with fault- and fracture-controlled fluid and gas flow.

Some vertical migration of the hydrate stability zone may be caused by accretionary processes or glacial-interglacial oceanographic variations (sea-level depth and bottom-water temperatures). This shift from glacial to warmer interglacial periods may lead to an

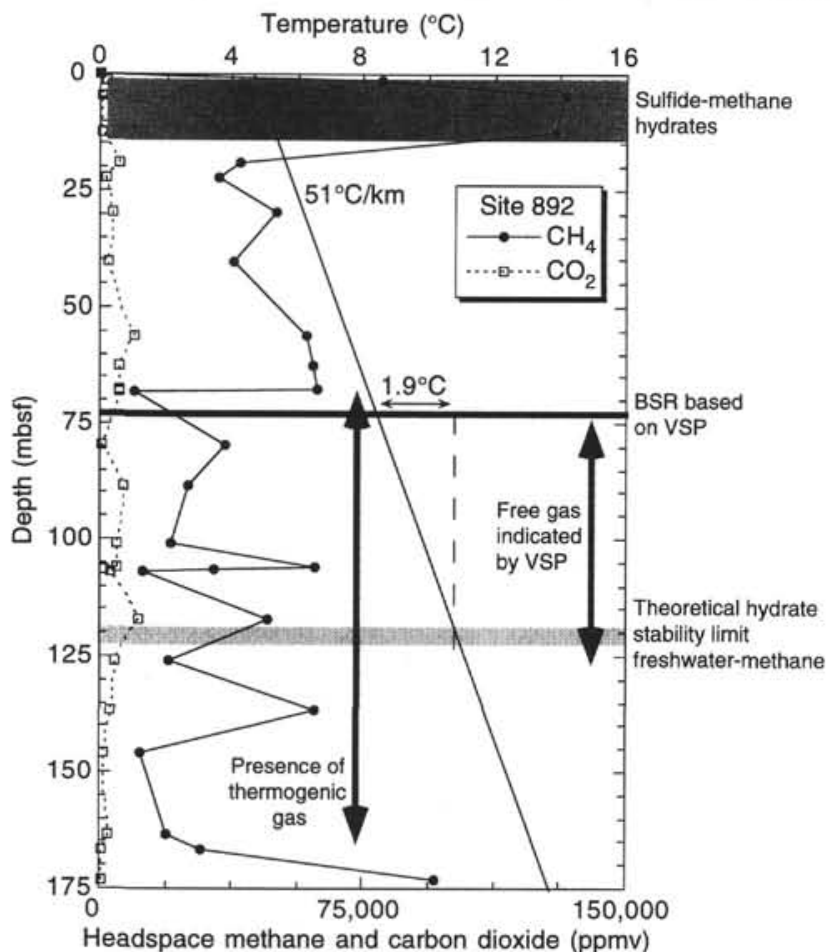

Figure 14. Summary depth plot of hydrate stability and distribution for Site 892.

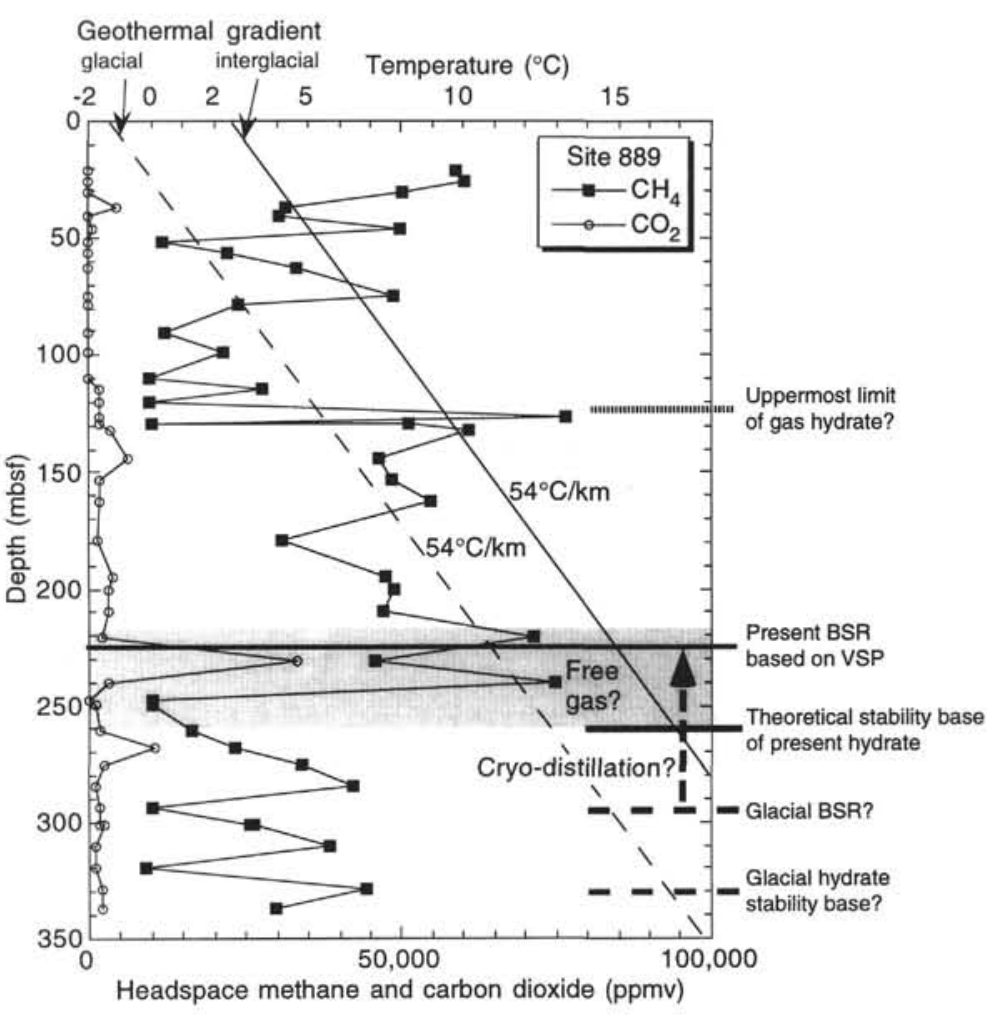

upward translation of the hydrate stability and a cryo-distillation of gases at the base of the hydrate zone. This may account for the free gas phase observed in the VSP.

\section{ACKNOWLEDGMENTS}

We would like to thank the crew of the JOIDES Resolution and $S E D C O / B P 47 I$ for outstanding drilling operations under very trying conditions and sometimes more dangerous situations during Leg 146. MJW would like to thank F. Harvey-Kelly for the desorption laboratory work and T. Cederberg for operation of the GC/C/IRMS. We would like to acknowledge a grant from the Nordic Research Council for analytical support (MH), and to NSERC for Strategic Research Grant STR0118459 (MJW).

\section{REFERENCES}

Claypool, G.E., and Kaplan, I.R., 1974. The origin and distribution of methane in marine sediments. In Kaplan, I.R. (Ed.), Natural Gases in Marine Sediments: New York (Plenum), 99-139.

Daniels, L., Fulton, G., Spencer, R.W., and Orme-Johnson, W.H., 1980. Origin of hydrogen in methane produced by Methanobacterium thermoautotrophicum. J. Bacteriol., 141:694-698.

Davis, E.E., and Hyndman, R.D., 1989. Accretion and recent deformation of sediments along the northern Cascadia subduction zone. Geol. Soc. Am. Bull., 101:1465-1480.

Davis, E.E., Chapman, D.S., Mottl, M.J., Bentkowski, W.J., Dadey, K., Forster, C., Harris, R., Nagihara, K., Rohr, K., Wheat, G., and Whiticar, M.J., 1992. Flankflux: an experiment to study the nature of hydrothermal circulation in young oceanic crust. Can. J. Earth Sci., 29:925-952.

Davis, E.E., Hyndman, R.D., and Villinger, H., 1990. Rates of fluid expulsion across the Northern Cascadia accretionary prism: constraints from new heat flow and multichannel seismic reflection data. J. Geophys. Res., 95:8869-8889.

Hitchon, B., 1974. Occurrence of natural gas hydrates in sedimentary basins. In Kaplan, I.R. (Ed.), Natural Gases in Marine Sediments: New York (Plenum), 195-226. 
Hyndman, R.D., and Davis, E.E., 1992. A mechanism for the formation of methane hydrate and seafloor bottom-simulating reflectors by vertical fluid expulsion. J. Geophys. Res., 97:7025-7041.

Hyndman, R.D., Yorath, C.J., Clowes, R.M., and Davis, E.E., 1990. The northern Cascadia subduction at Vancouver Island: seismic structure and tectonic history. Can. J. Earth Sci., 27:313-319.

Iversen, N., and Jørgensen, B.B., 1985. Anaerobic methane oxidation rates at the sulfate-methane transition in marine sediments from Kattegat and Skagerrak (Denmark). Limnol. Oceanogr., 30:944-955.

Katz, D.L., Cornell, D., Kobayashi, R., Poettmann, F.H., Vary, J.A., Elenbaas, J.R., and Weinaug, C.F., 1959. Water-hydrocarbon systems. In Katz, D.L., et al. (Eds.), Handbook of Natural Gas Engineering: New York (McGraw-Hill), 189-221.

Kulm, L.D., Suess, E., Moore, J.C., Carson, B., Lewis, B.T., Ritger, S.D., Kadko, D.C., Thornburg, T.M., Embley, R.W., Rugh, W.D., Massoth, G.J., Langseth, M.G., Cochrane, G.R., and Scamman, R.L., 1986. Oregon subduction zone: venting, fauna, and carbonates. Science, 231:561566.

Kulm, L.D., von Huene, R., et al., 1973. Init. Repts. DSDP, 18: Washington (U.S. Govt. Printing Office).

Kvenvolden, K.A., and Kastner, M., 1990. Gas hydrates of the Peruvian outer continental margin. In Suess, E., von Huene, R., et al., Proc. ODP, Sci. Results, 112: College Station, TX (Ocean Drilling Program), 517526.

MacKay, M.E., Moore, G.F., Cochrane, G.R., Moore, J.C., and Kulm, L.D., 1992. Landward vergence and oblique structural trends in the Oregon margin accretionary prism: implications and effect on fluid flow. Earth Planet. Sci. Lett., 109:477-491.

Marshall, D.R., Saito, S., and Kobayashi, R., 1964. Hydrates at high pressures, Part I. Methane-water, argon-water and nitrogen-water. AIChE J., 10:202.

Martens, C.S., and Berner, R.A., 1977. Interstitial water chemistry of anoxic Long Island Sound sediments. I. Dissolved gases. Limnol. Oceanogr., 22:10-25.

Moore, J.C., Orange, D., and Kulm, L.D., 1990. Interrelationship of fluid venting and structural evolution: Alvin observations from the frontal accretionary prism. J. Geophys. Res., 95:8795-8808.

Müller, P.J., and Suess, E., 1979. Productivity, sedimentation rate, and sedimentary organic matter in the oceans, I. Organic carbon preservation. Deep-Sea Res. Part A, 26:1347-1362.

Reeburgh, W.S., 1976. Methane consumption in Cariaco Trench waters and sediments. Earth Planet. Sci. Lett., 28:337-344.

Ritger, S., Carson, B., and Suess, E., 1987. Methane-derived authigenic carbonates formed by subduction-induced pore water expulsion along the Oregon/Washington margin. Geol. Soc. Am. Bull., 98:147-156.

Shipboard Scientific Party, 1994. Explanatory notes. In Westbrook, G.K. Carson, B., Musgrave, R.J., et al., Proc. ODP, Init. Repts., 146 (Pt. 1): College Station, TX (Ocean Drilling Program), 15-48.

Snavely, P.D., Jr., 1987. Tertiary geologic framework, neotectonics, and petroleum potential of the Oregon-Washington continental margin. In
Scholl, D.W., Grantz, A., and Vedder, J.G. (Eds.), Geology and Resource Potential of the Continental Margin of Western North America and Adjacent Ocean Basins-Beaufort Sea to Baja California. Circum-Pac. Counc. Energy Miner. Resour., Earth Sci. Ser., 6:305-336.

Suess, E., and Whiticar, M.J., 1989. Methane-derived $\mathrm{CO}_{2}$ in pore fluids expelled from the Oregon subduction zone. Palaeogeogr., Palaeoclimatol., Palaeoecol., 71:119-136.

Westbrook, G.K., Carson, B., Musgrave, R.J., et al., 1994. Proc. ODP, Init. Repts., 146 (Pt. 1): College Station, TX (Ocean Drilling Program).

Whiticar, M.J., in press. An acid/vacuum micro-extraction device for molecular and stable isotopic analysis of free and sorbed sediment gases. Anal. Chem.

Whiticar, M.J., and Cederberg, T., in press. Stable carbon isotope determinations of hydrocarbon gases at the picomole level by GC-C-IRMS. Anal.Chem.

, 1987. Carbon and hydrogen isotopes in gas samples from Leg 95, Holes 603D and 613. In Poag, C.W., Watts, A.B., et al., Init. Repts. DSDP, 95: Washington (U.S. Govt. Printing Office), 647-650.

1989. Molecular and stable isotope composition of headspace and total hydrocarbon gases at ODP Leg 104, Sites 642, 643, and 644, Vøring Plateau, Norwegian Sea. In Eldholm, O., Theide, J., Taylor, E., et al., Proc. ODP, Sci. Results, 104: College Station, TX (Ocean Drilling Program), 327-334.

Whiticar, M.J., Faber, E., and Schoell, M., 1986. Biogenic methane formation in marine and freshwater environments: $\mathrm{CO}_{2}$ reduction vs. acetate fermentation-isotope evidence. Geochim. Cosmochim. Acta, 50:693709 .

Whiticar, M.J., Faber, E., Whelan, J.K., and Simoneit, B.R.T., 1994. Thermogenic and bacterial hydrocarbon gases (free and sorbed) in Middle Valley, Juan de Fuca Ridge, Leg 139. In Mottl, M.J., Davis, E.E., Fisher, A.T., and Slack, J.F. (Eds.), Proc. ODP, Sci. Results, 139: College Station, TX (Ocean Drilling Program), 467-477.

Whiticar, M.J., and Suess, E., 1990. Characterization of sorbed volatile hydrocarbons from the Peru margin, Leg 112 , Sites $679,680 / 681,682$, 684, and 686/687. In Suess, E., von Huene, R., et al., Proc. ODP, Sci. Results, 112: College Station, TX (Ocean Drilling Program), 527-538.

Yorath, C.J., 1987. Petroleum geology of the Canadian Pacific continental margin. In Scholl, D.W., Grantz, A., and Vedder, J.G. (Eds.), Geology and Resource Potential of the Continental Margin of Western North America and Adjacent Ocean Basins-Beaufort Sea to Baja California. Circum-Pac. Counc. Energy Miner. Resour., Earth Sci. Ser., 6:283-304.

\author{
Date of initial receipt: 9 December 1994 \\ Date of acceptance: 29 May 1995 \\ Ms 146SR-247
}

